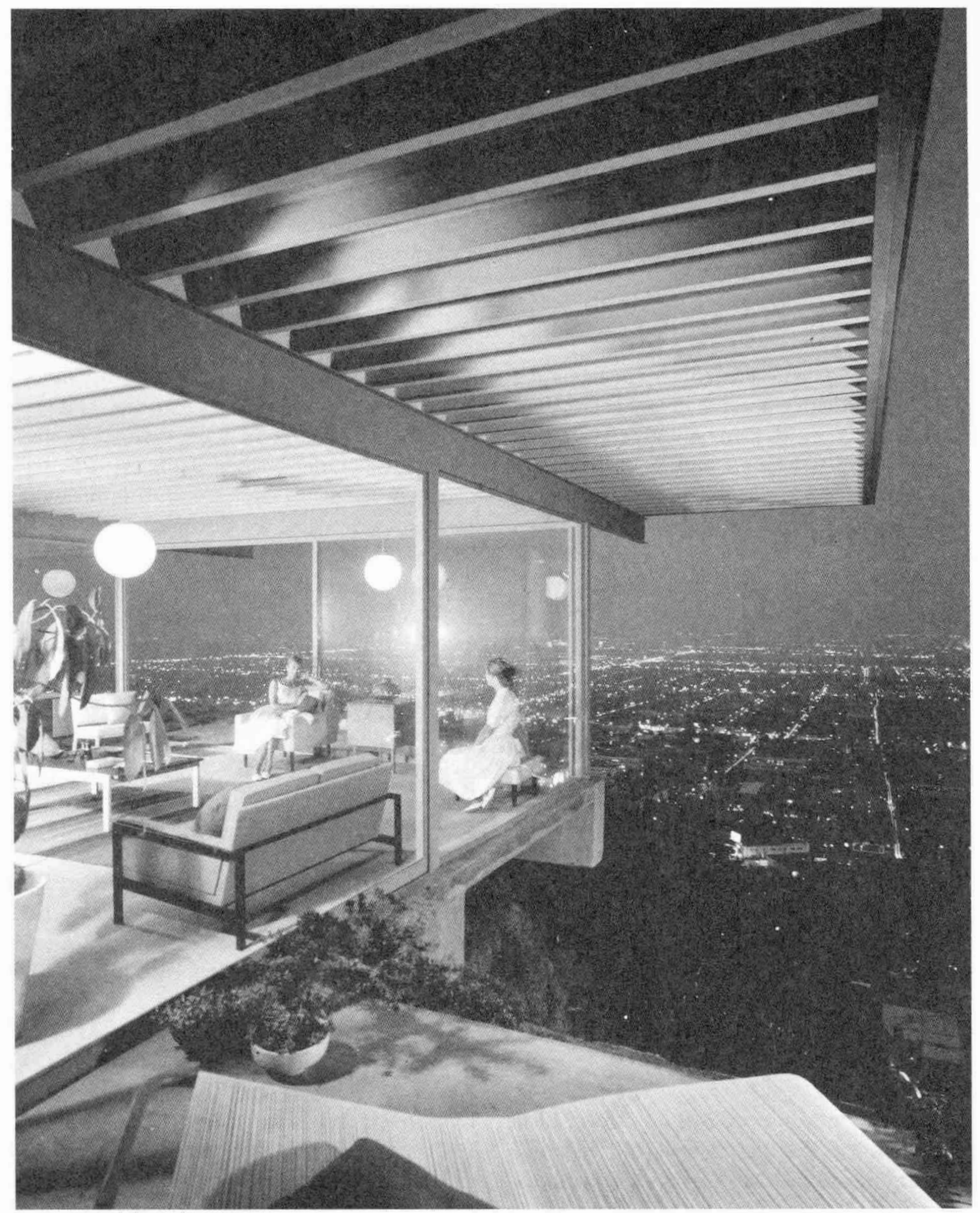




\section{Lucía Sala de Touron}

Historiadora y catedrática de la Facultad de Humanidades y Ciencias de la Educación-Universiclad de la República, Montevideo. Directora del Centro de Estudios Interdisciplinarios Latinoamericanos en la misma institución. Codirectora de la revista Enctentros. Durante su exilio entre 1976 y 1985 fue catedrática de la Facultad de Filosofía y Letras-UNAM. Autora de numerosas publicaciones sobre la historia de América Latina y Uruguay, entre las que destacan (en coautoría con Rosa Alonso Eloy) El Unuguay comercial, pastrnil y caudillesco, Ediciones de la Banda Oriental, Montevideo, 1986, 2 vols.; Artigas y su revolución agraria, 1811 -1820, Siglo XXI Editores, 2a. ed., México, 1987; Estructura económico-social de la colonia, Pueblos Unidos, Montevideo, 1967. Conjuntamente con José Luis Ávila y Teresa Aguirre está preparando una historia económical y social de América Latina en el siglo Xx en tres tomos. Asimismo, está por concluir un libro titulado La democracia esquiva, que versa sobre el uso del término en América Latina en el siglo xx.

\section{Resumen}

En las décadas de los cuarenta y cincuenta del siglo XIX, la democracia fue invocada en América Latina con viejos pero también con algunos nuevos sentidos. En este texto se analizan tres casos en que son expuestas distintas versiones de la época: el discurso de Esteban Echeverría en su exilio montevideano y los discursos de movimientos en que se reunieron jóvenes liberales, periodistas, profesionales, estudiantes, sobre todo, y artesanos en la Sociedad de la Igualdad chilena y las sociedades democtáticas colombianas. El democratismo radical, el utopismo socialista y las revoluciones europeas de 1848 influyeron poderosamente en estos casos, como sucedió en la mayor parte de América Latina. Los nuevos movimientos sociales y políticos de entonces y a comienzos del siglo $\mathrm{xx}$ tuvieron algunos nuevos actores. Las invocaciones a la democracia en el momento y por los movimientos mencionados muestran, sin embargo, que ya entonces estaban planteadas algunas de las versiones que adquirieron mayor desarrollo en el siglo pasado y forman parte de la agenda presente.

\section{Palabras clave:}

Democracia, movimientos sociales, América Latina, siglo XIX, Esteban Echeverría, liberales, Sociedad de la Igualdad, Chile, sociedades democráticas, Colombia.

\section{Abstract}

During the 1840 s and 1850 s, democracy in Latin America was invoked with new and old meanings. This text analyzes three cases that provide different versions of the era: the discourse of Esteban Echeverría during his exile in Montevideo, and the discourse of the movements that attracted young liberals, journalists, professionals and above all students, as well as artisans at the Sociedad de la Igualdad Chilena and the Colombian Sociedades Democráticas. Radical democracy, Socialist Utopianism and the European revolutions of 1848 wielded a powerful influence over these cases, as happened in most of Latin America. The new social and political movements of the time and at the beginning of the $20^{\text {th }}$ century had a number of new actors. The invocations of democracy at the time and the movements mentioned earlier show, however, that some of the versions that developed most fully during the past century and form part of the present agenda had already been put forward.

Key words:

Democracy, social movements, Latin America, $19^{\text {th }}$ century, Esteban Echeverría, liberals, Sociedad de la Igualdad, Chile, sociedates democráticas, Colombia.

Fecha de recepción: junio de 2004

Fecha de aceptación: agosto de 2004 


\title{
Democracia en América Latina: liberales, radicales y artesanos a mediados del siglo XIX
}

\author{
Lucía Sala de Touron
}

$\mathrm{E}$ n las proximidades del medio siglo una nueva generación de liberales, con aspiraciones a desempeñar un papel protagónico en el proceso político de sus países, expusieron un discurso crítico de las bases ideológicas y culturales del régimen vigente y un programa de cambios del sistema político, de la sociedad y de la economía. Algunos de ellos formularon sus aspiraciones con la terminología del democratismo radical y de las distintas versiones del utopismo "filosóf1co" europeo de su época. Entre estos últimos se contaron quienes habían cursado estudios en el extranjero o en universidades e institutos de nivel terciario en sus propios países, que integraron sociedades literarias o artísticas y escribieron en revistas culturales y en los periódicos, convertidos en herramienta de la polémica política.

Denunciaron la pervivencia de la colonia después de la independencia de un modo más radical y argumentado de lo que lo hicieran los liberales con anterioridad, rechazaron desde una perspectiva racionalista el predominio ideológico de la Iglesia católica, su función legitimadora del sistema y, en algunos casos, oponiendo al catolicismo oficial un Jesús humano y casi revolucionario. Adoptaron el romanticismo en la literatura y tomaron de éste su concepción social, atribuyéndose el papel de redentores del pueblo.

Secularizadores del Estado postularon la desamortización de los bienes del clero, sobre todo en aquellos lugares donde la Iglesia poseía o era acreedor hipotecario de grandes extensiones de tierra. En unos casos más que en otros, propugnaron descle el llano la pequeña propiedad. Defendieron libertades, derechos individuales y la legalidad, aunque, como en otros temas, no fueron consecuentes al llegar al gobierno. Propusieron la extensión del sufragio, que de todas maneras quedó limitado por razones de vecindad, por el filtro de la elección a varios grados, por la exigencia de ser alfabeto o de contar con ingresos obtenidos de manera independiente, aunque pudieron postergar el derecho al voto "universal" hasta que se extendiera la educación. También desde el llano postularon la supresión de la esclavitud, de los fueros y mayorazgos donde éstos pervivían, y de los gremios y corporaciones tradicionales. Sostuvieron la liberalización del comercio interno y la apertura al tráfico exterior, y fincaron el progreso en el flujo de capital y la inmigración.

$\mathrm{La}$ influencia del risorgimento italiano fue mayor en el sur de Brasil, en Buenos Aires en los años treinta y en Montevideo, donde veteranos de las luchas europeas 
integraron logias masónicas. Entre ellos Giuseppe Garibaldi, que desempeñó un importante papel durante la guerra de los Farrapos en Río Grande y en la defensa de Montevideo, sitiada desde 1843.

El discurso socializante de sectores radicales del liberalismo exhibió un perfil regenerador incluyendo cambios en el sistema social, sustentado en una visión optimista sobre el progreso material y el crecimiento espiritual del hombre.

La democracia constituyó uno de los puntos más importantes en su discurso, aunque coexistieron, como siempre, distintas versiones sobre la misma. En primer lugar, democracia fue opuesta a dictadura y caudillismo, y fue relacionada con una concepción del poder estatal limitado por constituciones y leyes, con libertades públicas y derechos individuales, en que la voluntad del pueblo -debidamente controlado- legitimara a las elites políticas que se proponían gobernar.

El discurso del sector del liberalismo denominado por sus detractores "jacobino" y hasta "rojo" coincidió durante un lapso con el de sectores de los artesanos, con quienes compartieron en oportunidades la utopía de una república de pequeños productores urbanos y rurales. ${ }^{1}$

Aunque ese chispazo democrático radical -y los sueños utópicos que lo acompañaron- constituye apenas un instante,

\footnotetext{
'Leal y Woldenberg, Clase, 1983, pp. 156-1.57. Según estos autores, los artesanos -fuerza importante durante la Reforma- esperaron construir en México una república de pequeños productores rurales y urbanos -estos últimos agrupados en organizaciones mutuales-, que una vez derrotado el régimen conservador podrían eludir el capitalismo y su explotaciön. Los autores consideran que ésta es una forma de populismo, que tendría un largo destino en ese país.
}

medido históricamente, presenta singular interés para enfocar los usos y la práctica de democracia en América Latina, objeto de este texto.

\section{LA MIRADA "ILUSTRADA" EN TORNO A LA DEMOCRACIA DE ESTEBAN EC HEVERRÍA}

La democracia fue uno de los temas recurrentes en el discurso de Echeverría a partir del Código o declaración de los principios que constituyen la creencia social de la república Argentina, publicado en 1839 en Montevideo y cuyas "palabras simbólicas" redactó, excepto la décima, debida a Juan Bautista Alberdi. La "creencia" se convirtió en el credo y manifiesto de la Joven Argentina, fundada en 1838 en Buenos Aires y transformada en sociedad secreta.

Había fracasado la esperanza de imprimir su proyecto en el gobierno que Rosas ejercía con plenos poderes en la provincia, y sus integrantes comenzaron a ser perseguidos por un gobierno que tildarían de tiranía. Entre 1838 y 1842 , y en particular en los primeros dos años -críticos para el rosismo-, la Joven Argentina fue un importante factor de oposición: fue capaz de unir y movilizar a un conjunto de fuerzas contra la "tiranía". Durante un corto lapso funcionaron filiales de la asociación en Montevideo con exiliados, en San Juan, en Tucumán y en Córdoba. Participaron o promovieron movimientos conspirativos e insurrecciones que fueron durísimamente reprimidas en la capital y en las provincias, contribuyeron a que el gobierno oriental, presidido por el general Fructuoso Rivera, declarara la guerra a Rosas cuando además Buenos Aires estaba bloqueada por una estación naval francesa. 
En los primeros años de la década de los cuarenta coincidieron en Montevideo algunos integrantes de la Joven Argentina -sector minoritario de los exiliados de ese país-, entre quienes se contaban, además de Echeverría, Juan Bautista Alberdi, Juan María Gutiérrez, Miguel Cané, Félix Frías, José Mármol y el muy joven Bartolomé Mitre. La mayoría de ellos tendría un importante papel en la vida cultural y política argentina luego de la caída de Rosas en 1852. Mitre y Domingo Faustino Sarmiento, que se exilió en Chile, ejercerían la presidencia de la nación entre 1862 y 1874.

Saint-Simon, uno de los referentes de la Joven Argentina, era conocido en Buenos Aires cuando aún llegaban revistas francesas. ${ }^{2}$ La concepción mazziniana que trasunta la "creencia" -incluso la denominación del grupo como Joven Argentinano fue ajena a la presencia de Gian Battista Cúneo, representante de la Joven Italia. $^{3}$

Este sector del exilio argentino contribuyó a crear el clima cultural y político montevideano de fines de los años treinta y comienzos de los cuarenta. En la pequeña ciudad-puerto floreció entonces el comercio encaminado hacia y desde su campaña, pero también hacia las provincias fronterizas de los estados vecinos. La mayoría de la población montevideana estaba formada por inmigrantes (aproximadamente los dos tercios de sus 31000 habitantes) y entre los europeos se contaban minorías políticas e ideológicamen-

${ }^{2}$ Desde enero de 1835 Pierre Leroux, a quien Echeverría admiraba, escribió en la Revue de Deux Mondes, y en 1836 fundó, junto a su amigo Jean Reynaud, la Encyclopedie Nouvelle.

${ }^{3}$ Fabbri, "Italianos", 1988, pp. 107-108. te activas, sobre todo italianos y franceses, una parte de los cuales profesaban ideas saint-simonianas, fourieristas, sismondianas, mazzinianas o eran cultores de Robert F. de Lamennais. Junto a liberales uruguayos -los más conocidos de los cuales fueron menos proclives al utopismo que los argentinos- escribieron en la prensa, en particular en $E l$ Iniciador y El $\mathrm{Na}$ cional dieron vida a los centros de enseñanza de la época, participaron en los torneos literarios, leyeron libros europeos de reciente publicación y discutieron en las peñas reunidas en los cafés.

Félix Frías ejemplifica, con su opción saint-simoniana, el radicalismo temporal de los jóvenes argentinos: "El oro es el móvil de los esclavos, de las facciones liberticidas. Pobres fueron Jesús, Rousseau y Saint-Simon, pobres los apóstoles todos de la religión democrática." Con una perspectiva que rememora el lenguaje de $\mathrm{Si}$ monde de Sismondi, el español Marcelino Pareja, por su parte, en la clase inaugural dictada el 1 de julio de 1841 en el Colegio de Humanidades, recordó que el problema fundamental en esos días lo constituía "la existencia de clases sociales antagónicas, propietarios, capitalistas y obreros", y anunciaba que la confrontación entre éstas subyacía en todos los conflictos políticos y morales y que la sociedad debía encaminarse hacia un orden social de una sola clase. ${ }^{4}$

${ }^{4}$ Sala de Touron y Alonso, Uruguay, 1991, t. II, pp. 20-25; Zubillaga, "Pensamiento", 1995, pp. 201-234. Montevideo era sólo la cabeza de un jequeño país casi despoblado. Los inmigrantes no eran todos revolucionarios más o menos utópicos. Junto a algunos hombres y pocas familias con algún capital o profesión universitaria, llegaron artesanos, marinos, gentes que levantaron un pequeño comercio y cam- 


\section{Echeverria en su exilio montevideano}

A diferencia de la mayoría de los integrantes de la generación del 37, Echeverría vivió en condiciones muy difíciles en Montevideo durante los nueve años que duró el Sitio Grande, impuesto en febrero de 1843 por las fuerzas uruguayas y argentinas al mando del presidente oriental derrocado en 1838, el general Manuel Oribe. Aislado en forma creciente del resto de los allí exiliados, Echeverría apostó a distintos proyectos para contribuir a la caída de Rosas y también para "regenerar" a Argentina, convencido de la imposibilidad de revivir el sistema previo al gobierno de Rosas. Había fracasado el intento previo al sitio de derrocar al gobierno bonaerense con la Guerra Grande iniciada en 1839. Más tarde Echeverría experimentó, como tantos otros, las humillaciones infligidas por la intervención francoinglesa. Se frustró en 1946 su proyecto de creación de un partido nacional de oposición a Rosas, atrayendo a caudillos federales de Entre Ríos y Corrientes y tampoco se concretó su esperanza de que

pesinos, la mayoría de los cuales llegó con la esperanza de "hacer la América". Fuera de Montevideo y unas pocas ciudades, villas y pueblos pequeños, la campaña ganadera, salvo pequeños retazos agrícolas casi despoblada, sólo estaba salpicada por algunas estancias o postas donde cambiar las caballadas. La esclavitud sería abolida en 1842, y los libertos integraron los batallones que defendieron Montevideo. Pocos años antes habían sido destruidas las tribus charrúas mediante la campaña militar de 1831 , aunque sobrevivieron hombres y la "chusma" de mujeres y niños fue repartida entre las familias patricias. Proseguía la lenta conversión al peonazgo de los "gauchos", que fueron integrados no siempre de manera voluntaria a las fuerzas enfrentadas en las guerras civiles. las revoluciones del 48 repercutieran en el Plata a la manera de la de 1789.

El autor de la "creencia" ya había muerto cuando Rosas se exilió en Inglaterra en 1852, luego de ser derrotado por las fuerzas comandadas por el gobernador entrerriano, general Justo José de Urquiza.

Echeverría no sólo apostó a las alianzas de tipo militar y político, sino que en 1846 buscó sentar las bases ideológicas del nuevo partido, haciendo a tales efectos una revisión del pensamiento y las prácticas políticas a partir de la independencia. Tal fue el objetivo principal de su texto Antecedentes de la Asociación de Mayo, precedida por una ojeada retrospectiva sobre el movimiento intelectual en el Plata desde el año 1837, conocido como "Dogma socialista".

Ya en la "creencia" había buscado explicar el hecho irrebatible de que Rosas no sólo asentaba su poder en el terror, sino que contaba con el apoyo de los sectores populares, cuya organización había sido refuncionalizada para asegurar su adhesión sin fisuras. Uno de sus recursos argumentales había consistido en aducir que el pueblo había confundido democracia ejercida de acuerdo con la razón, con soberanía ilimitada. ${ }^{6}$ Era aceptable para

${ }^{5}$ Echeverría, Obras, 1951, vol. I, pp. 153-198. Entre sus textos no literarios más importantes destacan sus "Discursos de introducción" a una serie de lecturas pronunciadas en el Salón Literario en septiembre de 1837, "El pensamiento de Mayo, antecedentes y primeros pasos de la Revolución de Mayo", "La contrarrevolución", "La Revolución de Febrero. Origen y naturaleza", y cartas y textos para la enseñanza.

${ }^{6}$ Rosas supo llegar a las mayorías con su lenguaje llano, su trato directo, su destreza en las tareas rurales, al tiempo que negoció y reprimió a los indios. Su gobierno ejercido con plenos poderes en Buenos Aires desde 1835 contribuyó decisivamente a imponer un 
Echeverría que durante las luchas por la independencia, necesitados del imprescindible apoyo popular, los revolucionarios no se preocuparan de aclarar tal confusión. Criticó en cambio el error de los unitarios al suponer que funcionarían instituciones representativas, creyendo que podrían controlar a quienes habían concedido en 1821 el sufragio "universal". Recordaba que un tercio de ellos no votaba y que otro tanto "no sabía por qué ni para qué votaba". Como resultado, un pueblo ignorante había encumbrado a ambiciosos y, en definitiva, había permitido que Rosas utilizara para adueñarse de la totalidad del poder la aprobación "monstruosa de una turba de imbéciles y traidores". ${ }^{7}$

La democracia, que Echeverría declaró esencia de todos los gobiernos, no consistía en su opinión sólo en ausencia de dictadura, ni tenía carácter puramente político. Ya en la primera versión de la "creencia", donde junto a la libertad incluye la igualdad como esencia de la democracia, pueden inferirse requerimientos de tipo social, además de los políticos, para su vigencia. Entre los principales impedimentos para la democracia anota el que no todos puedan acceder a empleos y recompensas, la existencia de privilegios corporativos, el hecho de que la clase "rica

orden disciplinario sobre ese pueblo en cuyo nombre gobernaba. Utilizó el terror contra la oposición, eliminó todas las formas de asociación libre y convirtió a las que pervivieron en instrumentos de su política. Entre ottos autores que han hecho aportes originales sobre el tema véanse González, Civilidad, 2000, pp. 38-118; Chiaramonte, "Federalismo", 1996, pp. 81132; Ternavasio, "Deliberación", 1998, pp. 159-188; Gelman, "Gigante", 1998, pp. 223-240.

${ }^{7}$ Echeverría, Obras, 1951, vol. I, p. 330. se sobrepone, y tiene más fueros que las otras", y que las cargas, sobre todo las más pesadas, sean arrojadas sobre los pobres. Se proclama allí la inmoralidad de un régimen que no protege "a los débiles, los pobres", es decir, que no emplea "los medios que la sociedad ha puesto en su mano para realizar la igualdad". Atribuye en consecuencia al Estado una función reparadora al referirse a "la extensión de las luces y el bienestar de los ciudadanos".

En un texto publicado posteriormente, donde se incluyen discursos supuestamente pronunciados en 1837 en Buenos Aires, había acusado a los sucesivos gobiernos de su país de desinteresarse del pueblo y de los pobres y pregunta: “ ¿Cuándo han echado una mirada compasiva a sus necesidades, a su ignorancia o a su industria?" Recuerda que la sangre de los pobres corrió con la independencia, que se los afecta con impuestos, se traba su industria y se les impide disfrutar de la propiedad.

Se ha proclamado la igualdad y ha reinado la desigualdad más espantosa; se ha gritado la libertad y ella sólo ha existido para un corto número, se han dictado leyes y éstas sólo han protegido al poderoso. Para el pobre no hay leyes ni derechos individuales sino violencia, sable, persecuciones, injusticia.?

Cuando Echeverría escribe el "Dogma", había hecho precisiones en su concepción sobre la democracia política. Según Juan María Gutiérrez, Echeverría había propugnado un "sistema administrativo 'democrático', es decir, un sistema en el que participara el mayor número de personas en el manejo de los intereses co-

\footnotetext{
"Echeverría, "Código", 1977, pp. 98-99.

'Echeverría, "Discurso", 1951, vol. I, pp. 216-217.
} 
munes" ${ }^{10}$ En las cartas a los gobernadores de Entre Ríos y Corrientes, Justo José de Urquiza y Joaquín Madariaga habían propuesto en 1846 un gobierno federal y concedido un papel importante al municipio, donde debía iniciarse la ampliación del sufragio:

Queremos, pues, en la organización nacional la soberanía de cada provincia en todo lo relativo a su régimen unitario, y la erección de un gobierno central para la gestión de los intereses y la dirección de los negocios generales de la confederación [...] Creemos, además, que la organización del sistema municipal es la única que puede asegurar de un modo permanente a los argentinos el goce de la fraternidad, la igualdad, la libertad y el progreso pacífico de su país. ${ }^{11}$

En el texto publicado el mismo año que el "Dogma socialista" bajo el título de "Segunda lectura", donde historiza el proceso económico de su país, enfatiza la necesidad de transitar hacia una era industrial transformando lo que brinda la naturaleza mediante el trabajo y en bien del hombre. Para esto era necesario que el gobierno prescindiera de restricciones y que proporcionara protección, fomento y libertad.

Echeverría hizo una minuciosa reconstrucción-construcción de la historia del periodo revolucionario y de las dos corrientes enfrentadas desde entonces: la primera, revolucionaria, había propugnado no sólo la independencia política, sino la emancipación de todo lo que había significado la colonia. La otra, contrarrevo-

${ }^{10}$ Gutiérrez, "Noticias", 1977, p. 139.

${ }^{11}$ Echeverría, "Carta", 1951, vol. I, pp. 271-273. lucionaria, había bregado aun en el país independiente por mantener ese mundo colonial que pervivía con Rosas. La primera, que se caracteriza como una etapa en la ley del progreso "promulgada por la Revolución de Mayo" se inscribió en "la ley del desarrollo democrático de la sociedad". ${ }^{12}$ Este discurso fue también herramienta de la batalla ideológica contra el repertorio empleado desde la otra orilla del Plata, que incluía la condena de los opositores como aristócratas, ajenos a las esencias nacionales y americanas, desconocedores de las virtudes sencillas del hombre común y de la armonía rural. Su versión más refinada era expuesta en el Archivo Americano por Pedró de Angelis, quien descalificaba a Echeverría por su utopismo. Éste, por su parte, que no siempre se limitó a argumentar en el plano de las ideas, tildó a De Angelis de ignorante y lo calificó despectivamente de "compadrito mazorquero". ${ }^{13}$

Echeverría confió en los efectos de la revolución europea para modificar la situación de su patria. En el texto sobre la Revolución de Febrero, con lenguaje propio del artesano, editor y militante, Pierre Leroux anuncia "la era de la completa emancipación del hombre", aunque recuerda que en la mayor parte de las sociedades cristianas el despotismo de la familia-casta iba desapareciendo, en algunas pervivía el "despotismo de la patria o del Estado-casta", pero "el despotismo de la propiedad-casta" dominaba aún en Europa. De ahí derivaba "la explotación del hombre por el hombre, o del pobre por el rico", de ahí "el proletarismo, forma pos- 
trera de la esclavitud del hombre por la propiedad". ${ }^{14}$

Más allá del lenguaje empleado, este texto tenía sentido, además, por lo menos en los siguientes aspectos: en cuanto a que la revolución europea venía a reivindicarlo de las acusaciones de utopismo lanzadas no sólo desde Buenos Aires, sino por parte del exilio argentino, y porque reforzaba su convicción de que a la caída de Rosas debía producirse la ansiada regeneración.

Si en otros países las revoluciones europeas operaron como estímulo y detonante de movimientos y hasta de alguna "revolución", en plena Guerra Grande en el Plata su efecto inmediato fue el retiro de la flota francesa que bloqueaba Buenos Aires. En Europa, sea por el sesgo que tomó cada proceso nacional, o por la intervención extranjera, fueron sofocadas o derrotadas las corrientes democráticas, socialistas y republicanas y frustrados los procesos de unidad o de independencia nacionales, abriéndose una etapa conservadora. La derrota de la revolución en Italia obligaría a Garibaldi y otros republicanos, incluido Giuseppe Mazzini, a emigrar, mientras no pocos morían, sufrían cárcel o destierro. Garibaldi ya no regresó a su antigua pieza alquilada en una vivienda en la Ciudad Vieja. Allí habían nacido los hijos concebidos con su compañera riograndense, Anita, una de las mujeres más destacadas de su época que murió durante la marcha de los Camisas Rojas, que no lograron impedir la caída de la re-

14 Echeverría, "Sentido", 1995, p. 168. Leroux fue un autodidacta de inspiración saint-simoniana, quien participó activamente en el 48 francés y debió emigrar de Francia cuando ascendió el Partido del Orden que llevó a la presidencia a Luis Bonaparte. pública de Venecia, doblegada por las fuerzas austriacas.

Cuando Echeverría había escrito el "Dogma socialista", sus antiguos compañeros exiliados en otras repúblicas vecinas y mayoritariamente en Chile, si bien mantenían afecto y consideración hacia el que fuera en cierto modo su mentor, no mostraron interés en acompañar su proyecto regenerador. Sarmiento, quien lo visitó en 1846, calificó de lucubraciones las ideas que le había expuesto. Para entonces, la mayoría de ese exilio intelectual argentino, que junto a otros hispanoamericanos contribuyó al florecimiento cultural en los años cuarenta en Chile, agradecía la hospitalidad y admiraba un orden conservador que contraponía a la tiranía de Rosas y que estimaba el único régimen posible entonces para los pueblos americanos.

No sólo se mostraron poco afectos a seguir a Echeverría, sino alejados ya de las ideas que defendieran en su juventud. No acogieron con el fervor de los jóvenes liberales chilenos la Historia de los girondinos de Alfonse de Lamartine. ${ }^{15}$ En Chile la simpatía inicial bastante generalizada por la Revolución de Febrero pronto se transformó en desilusión y crítica. Muy pocos emigrados argentinos apoyaron a los Iguales y al conjunto de la oposición liberal en 1851. Por el contrario, los que residían en Copiapó, entre ellos Carlos Tejedor, lucharon contra la insurgencia levantada en el norte y que se impuso en La Serena, intentó levantarse en Valparaíso y envió un ejército hacia Santiago. Estaban "interesados en comprometer la gratitud del gobierno chileno" -según expresa el historiador conservador Francisco

\footnotetext{
15 Vicuña, Girondinos, 1989, pp. 29-33.
} 
Encina- $\mathrm{y}$ apoyaron a las fuerzas del gobierno con la esperanza de que éste "les dejara organizar en Copiapó una expedición que amagaba contra Rosas". ${ }^{16}$

El artículo de Sarmiento publicado en Crónica, al conmemorarse un año de la Revolución de Febrero, es ilustrativo no sólo por su balance de aquellos hechos, sino por su punto de vista en materia política y social. Era entonces un destacado periodista y ya reconocido escritor, sobre todo por su Facundo. Civilización y barbarie, publicado en 1845 . Había sido primer director del Colegio de Preceptores, designado por el conservador Manuel Montt, quien financió su viaje a Europa y Estados Unidos con el fin de que estudiara sus sistemas educativos.

En el artículo de Crónica, Sarmiento elogia los elevados principios y algunas de las leyes proclamadas por la "república democrática" "la parte más avanzada de la especie humana". Explica la elección a la presidencia de Luis Bonaparte por "la incapacidad de las masas para juzgar sobre el bien público, cuando no se las ha consentido prepararse a la vida política". A la educación le correspondería, en su opinión, dulcificar las costumbres de "los bárbaros que todas las sociedades contienen en su seno". Contrasta con las ideas echeverrianas su recomendación, en la formación de los ciudadanos, respecto de evitar decir que "las insignificantes luchas de la industria son la guerra del rico contra el pobre, que esa idea lanzada en la sociedad puede un día estallar."17

Bien mirado, Sarmiento explica por la ignorancia de las masas francesas la elección de Bonaparte, así como había ex-

\footnotetext{
${ }^{16}$ Encina, Historia, s. a., t. xxıv, p. 52.

17 Sarmiento, "Revolución", 1995, pp. 174-176.
}

plicado el caudillismo en el Plata como producto de la barbarie de su población rural, herencia española, resultado de la mezcla de razas y de la influencia del "desierto", esa tierra casi despoblada donde vagabundeaba el gaucho nómada. ${ }^{18}$

Admirador de la experiencia estadunidense y en particular del papel de sus instituciones, de su democracia y de la educación común, encuentra en ella un modelo más atractivo que el europeo, con sus millones de miserables en las ciudades, sin perjuicio de las críticas que mereció su sistema en varios aspectos.

Alberdi, por su parte, desarrolló ideas básicas del régimen portaliano que, con una perspectiva hispanoamericana, consideró modélico y del cual admiró su eficacia modernizadora y su capacidad para imponer el orden y la paz y a cuya Constitución sólo reprocha no incluir la libertad de comercio e industria. En su amplia producción, escrita durante su larga vida y en la que trasunta la influencia de las teorías y los procesos de su época, mantuvo en lo esencial la convicción de que en los nuevos estados, hasta poco antes monarquías, el único gobierno viable era el que podía asumir las facultades de un rey "en el instante en que la anarquía le desobedece como gobierno republicano"."

En 1847 justifica su adhesión y su participación juvenil en la Guerra Grande y su apoyo a la intervención francesa contra Rosas. Confía en el futuro de su patria rica y pasible de atraer inmigración europea. Resalta el aporte de esa emigración argentina cuya madurez debía aventar te-

${ }^{18}$ Halperin, "Estudio", 1995, pp. 38-41. El autor hace un agudo análisis del pensamiento) argentino de la época y sus principales expositores.

19 Ramón, Breve, 2001, pp. 75-78. 
mores a su respecto. Piensa que el orden esencial que requería su país podría ser alcanzado mediante una Constitución superadora del despotismo legal o ilegal existente. $^{20}$

En las Bases, publicado por primera vez en Chile en 1852 y poco después en Argentina, finca su proyecto político en la transformación de la sociedad misma. ${ }^{21}$

¿Cómo hacer para pasar de nuestras democracias en el nombre a democracias en la realidad?, se pregunta. La democracia, cuya plena consecución posterga al futuro, así como la consolidación de la nación y el progreso, sólo se podría lograr con la afluencia de capitales y principalmente con el cambio mismo de la población merced al ingreso de inmigrantes, particularmente anglosajones, laboriosos y portadores de las prácticas de self government. Aunque no niega la importancia de la educación, que debía prescindir de sus tendencias librescas y adoptar un carácter práctico, la fundamental tarea del gobierno argentino era poblar esa tierra entonces casi desierta y en la que las ciudades, separadas por inmensas distancias, carecían de vías de comunicación adecuadas. Alberdi había apostado en 1852 a una confederación de provincias iguales en derechos, sin cuestionar en lo inmediato el tipo de gobierno ejercido por sus caudillos, dentro del marco constitucional y con una presidencia fuerte, criterio que no habría de modificar. Responsabilizaría al monopolio aduanero de Buenos Aires de las dificultades para la organización

${ }^{20}$ Alberdi, "República", 1995, pp. 117-128.

${ }^{21}$ Alberdi, Bases, 1914. En los últimos 20 capítulos Alberdi analiza la situación y expone sus ideas sobre la organización de Argentina, e incorpora un proyecto de Constitución. del país. Desde muy temprano había considerado que Rosas era un producto de las características del pueblo; en 1839 , actuando como secretario del presidente oriental general Fructuoso Rivera, había justificado de la misma manera la necesidad de reforzar al poder ejecutivo. Había desempeñado un papel no menor en la conformación de la alianza antirrosista y apoyado la intervención francesa. En los años finales de Rosas en Inglaterra se aproximó al proscripto; para entonces se enfrentaba a la política puesta en práctica por Mitre y Sarmiento desde la presidencia, a la guerra de la Triple Alianza contra Paraguay y a lo que consideró su falta de nacionalismo. ${ }^{22}$

Bartolomé Mitre fue uno de los pocos emigrados que habían participado en el movimiento liberal e incluso había sido encarcelado en Valparaíso en 1851. En Argentina encabezó una de las corrientes políticas más influyentes en los años posteriores a Rosas y desempeñó un papel decisivo en la construcción del Estado nacional basado en el predominio de Buenos Aires. Como gobernador de la provincia, segregada de la Confederación Argentina, derrotó a Urquiza en Pavón y ocupó la primera presidencia posrosista a partir de 1862. Llevó la guerra a Paraguay aliado con el imperio de Brasil y con el gobierno colorado uruguayo del general Venancio Flores, a quien contribuyó a imponer, y combatió tenazmente al caudillismo provincial.

Fue partidario de un liberalismo con nuevas formas de hacer política, incluyendo actos públicos, debates por la prensa y con una sociedad civil relativamente autónoma, pero contrario a los partidos

22 Botana, "Liberalismo", 1996, pp. 227-228. 
que dividían a los pueblos, excepto el suyo. Mitre fue uno de los más brillantes constructores de una historia que fundaba en la Revolución de Mayo no sólo la independencia, sino la democracia misma. Reivindicó el unitarismo de Bernardino Rivadavia, considerándolo un eslabón de la cadena que culminaba en sus ideas y su gobierno. ${ }^{23}$

Para Mitre la democracia era "el gobierno de todos y para todos", la libertad y el partido Libertad, que consideraba defensor de las instituciones.

Contrapuso esta concepción de la democracia con la "exageración de la democracia y la igualdad que ha pretendido igualar a la inteligencia con la barbarie, en vez de levantar las masas hasta la altura de la inteligencia". Reconocía a esas masas bárbaras, igualitarias y anárquicas, no obstante haber creado las condiciones para la república y la federación. Esta democracia exagerada había sido utilizada para encumbrarse por los caudillos "descendientes de Artigas" entre los que incluye a Rosas. ${ }^{24}$

\section{JÓVENES LIBERALES Y ARTESANOS} en aCCIÓn en ChILE y Nueva Granada

Un rasgo común a Chile y Nueva Granada a mediados del siglo XIX fue la participación conjunta de jóvenes liberales y

${ }^{23}$ Ibid., pp. 230-240; González, "Clubes", 1996, pp. $142-160$.

${ }^{24}$ Mitre, "Profesión", "Libertad", "Ideas", artículos publicados en el periódico Los Debates, en 1857, citados en Halperin, Proyecto, 1995, pp. 312 313. Mitre calificará a José Artigas como "caudillo de la democracia semibárbara" y afirmará que el pueblo "adoró en él su propia hechura" en Historia, 1983, t. III, p. 226. artesanos urbanos -a veces denominados obreros o trabajadores manuales- en la vida política de sus respectivos países. Tanto la Sociedad de la Igualdad chilena como las sociedades democráticas neogranadinas fueron organizaciones de tipo político que incluyeron artesanos con sus reivindicaciones inmediatas $y$, en el caso de las segundas, con un programa de transformación de la sociedad, Difirieron en esto de las corporaciones, cofradías y las mutualidades, y se diferenciaron también de las anteriores modalidades de participación en la vida política tras caciques o caudillos: supusieron un ensayo de participación colectiva y organizada.

En diversos países hispanoamericanos los artesanos habían demandado, mediante petitorios y movilizaciones, medidas de protección a sus producciones ante la competencia de los bienes importados. A diferencia de Inglaterra y el continente europeo, donde se extendía la industrializaciốn y el obrero coexistía con el artesanado pauperizado, los artesanos sufrían en Hispanoamérica la competencia de la industria europea y en particular de la britânica.

En Chile, en años de crecimiento del mercado urbano y de paz, los artesanos -en algunos casos inmigrantes- seguían proveyendo no sólo a un amplio sector medio y popular en buena parte del país, sino también, en algunos rubros, a las clases altas, que eran las principales adquirientes de productos importados. De todas maneras, el trabajo estable y la protección a la industria artesanal fueron demandas de los artesanos también en Chile.

A comienzos de los años cincuenta la Sociedad de la Igualdad y las sociedades democráticas, dirigidas por una nueva generación de liberales con formación 
intelectual y por artesanos autodidactas, se orientaron a incorporar al artesanado, diferenciado del bajo pueblo que, además de movilizarse tras caudillos o caciques, irrumpía con violencia en particular ante la falta o la carencia de los alimentos, cúando sufrían mayor rigor policial o simplemente manifestando el rencor inevitable y un cierto placer al desconocer la autoridad con la destrucción y el saqueo. Las fuentes con que contamos para aproximarnos a este tema son, fundamentalmente, los partes policiales y las descripciones de viajeros o gentes "decentes", cuyos relatos no fueron precisamente objetivos.

El populacho, sin embargo, no siempre fue incorporado mediante relaciones de tipo clientelar, o irrumpió esporádicamente. Su estallido fue a veces determinado por motivaciones patrióticas, como sucedió, por ejemplo, en México. Allí, en la coyuntura excepcional de la ocupación estadunidense de la capital en 1847, la plebe, "agrupada en montoncitos", "el sombrero echado sobre los ojos", se encolerizó al ver ondear la bandera de las franjas y estrellas en el Palacio Nacional, arrojando todo lo que pudieron calle a calle y casa a casa. ${ }^{25}$

En Chile el gobierno de Diego Portales había impuesto un orden conservador que no se había podido imponer en México, donde, según John Coatsworth, lo impidió la combinación de la acción de los liberales y las revueltas campesinas. ${ }^{26}$

${ }^{25}$ Moreno, "Trabajadores", 1983, t. I, pp. 347348. El artículo de Moreno Toscano es singularmente ilustrativo acerca de las formas de control social y político de los trabajadores formales e informales en la ciudad de México, tema que ha sido menos estudiado para otras ciudades hispanoamericanas.

${ }^{26}$ Coatsworth, "Patrones", 1988, p. 55.

\section{La SOCIEDAD DE LA IGUALDAD CHILENA}

El sistema portaliano fue controlado hasta la década de los sesenta por conservadores, y la solidez del Estado institucionalizado fue excepcional en Hispanoamérica en la época.

Los Iguales tuvieron a mediados del siglo XIX una incidencia política menor y durante un lapso más corto que las sociedades democráticas neogranadinas. El discurso igualitario tampoco cuestionó la propiedad.

En ningún caso la Sociedad de la Igualdad se planteó nuclear al populacho que se arracimaba en las zonas periféricas de Santiago, como resultado sobre todo de la inmigración interna. Aunque no se propone utilizar democracia como categoría, es interesante su empleo por el escritor José Joaquín Vallejo al referirse a los habitantes de una población popular ubicada a la entrada de Santiago, a la que define como uno de esos "hormigueros de democracia, siempre en gresca y algazara", tal vez por igualitaria y conflictiva. ${ }^{27}$ Sarmiento, por su parte, en un fragmento sugerente respecto de su opinión, caracteriza no sin simpatía a ese "pueblo pillo, trabajador e industrioso" al que las "gentes buenas y decentes" denominan de manera impiadosa "canalla, plebe, vulgo, muchedumbre, populacho, chusma".

Por su parte los maestros, y especialmente los de algunos oficios, constituían una protoburguesía con sus asalariados, diferenciada del pequeño productor con trabajo familiar, de los oficiales asalariados y de los aprendices, muy numerosos en Santiago y otras ciudades.

\footnotetext{
${ }^{27}$ Citado por Ramón, "Mecánica", 1994, p. 6.

${ }^{28}$ Ibid., p. 7.
} 
La novedosa participación politica en los años cuarenta

El entierro de un prócer liberal se había transformado en una manifestación cuya mayor novedad sería la participación juvenil, especialmente estudiantil y de los artesanos. Una de las más tumultuosas de esas expresiones colectivas se había realizado en 1844 en apoyo a Francisco Bilbao, autor de "La sociabilidad chilena", artículo publicado en la revista literaria El Crepúsculo. El joven autor había planteado en ese texto una interpretación de la historia misma, y en particular de la chilena, como contraposición entre el pasado colonial que aún pervivía, legitimado por la Iglesia, y la revolución. Afirmaba la necesidad de que la primera etapa de ésta, iniciada en 1810 , fuera completada. Hablaba de la importancia de una creencia que la fundamentara y de recuperar la soberanía popular que permitiera su realización. "Completar la revolución [expresaba] es apoyar la democracia en el espíritu y la tierra, en la educación y la propiedad."

Es interesante su análisis del papel de la estructura familiar, de la condición de la mujer y el sometimiento de los hijos como base del sistema autoritario. ${ }^{29}$

El texto de Bilbao fue condenado como inmoral y blasfemo, fue decretada su quema por mano del verdugo y el autor fue expulsado del Instituto Nacional, después de lo cual, y luego de unos meses como periodista en Valparaíso, marcharía a Francia. Allí continuó sus estudios, conoció a Edgard Quinet, Jules Michelet y Lamennais, entre otros, se vinculó con exi-

${ }^{29}$ Bilbao, "Sociabilidad", 1941, pp. 73-124. liados políticos europeos y participó en la Revolución de Febrero. Su figura casi legendaria, pese a su juventud, era admirada, sobre todo, por los jóvenes liberales.

Este dandy refinado, humanista y utópico, con vetas saint-simonianas, pero también con un bagaje importante de lecturas de otros autores, regresaría en 1850 a su patria, con la esperanza de que allí triunfara una revolución que no había sido victoriosa en Europa.

En 1845 se habían producido en Santiago agitaciones liberales. Al año siguiente, signado por la elección presidencial, se impuso el Estado de sitio invocando la prédica de $E l$ Pueblo -periódico de escasa difusión-, que denunciaba la penosa situación de las mayorías y el autoritarismo gubernamental. De todas maneras, fue reelegido en la presidencia el general Manuel Bulnes. El hecho más dramático del momento había ocurrido, sin embargo, en Valparaíso, donde una veintena de personas reprimidas por el ejército murieron en medio de la lucha electoral. ${ }^{30}$

Connotados pelucones integraron la sociedad El Orden, que respaldó al gobierno. Es significativo que llevara el nombre de Sociedad Democrática, en oposición a la anterior, la constituida por jóvenes y algunos antiguos liberales. En la Sociedad Caupolicán, que apelaba a las tradiciones históricas de resistencia y algunos de cuyos integrantes denunciaron la situación de los trabajadores, llegaron a revistar entonces unas decenas de artesanos.

No era irrelevante que se empleara el término democracia en el nombre de una sociedad, cuando en Chile ésta había sido expresamente postergada en nombre de

${ }^{30}$ Collier y Sater, Historia, 1998 , p. 104. 
la falta de virtudes y la ignorancia de las mayorías.

En los años treinta la democracia había perdido la nota jacobina que tuviera en las proximidades de la revolución francesa. Durante la monarquía orleanista se contaron incluso monárquicos entre los defensores de la democracia en Francia, y en Inglaterra la corriente socialista de los cartistas no se proclamó republicana. ${ }^{31}$ No obstante, en Europa continental, república, democracia y revolución se entrelazaban en el discurso radical. Su articulación con diferentes ideologemas del utopismo apuntaba además a promover cambios en la sociedad y a una "sociabilidad" enten-dida como asociación voluntaria y diferente de las formas asociativas previas, como los gremios y cofradías. Las sociedades secretas actuaban en Europa bajo monarquías absolutas y, aunque no siempre de manera explícita, unían república, democracia y, en algunos casos, aso-

${ }^{31}$ El ministro orleanista François Guizot consideró que había democracia porque no pervivían diferencias (legales). El fourierista Victor de Considérant rechazó la revolución y relacionó con la democracia la supresión de la durísima explotación obrera. Alexis de Tocqueville en La democracia americana, decía que ésta radicaba principalmente en la igualdad de "estatus y consideración" en el seno de la sociedad estadunidense. El partido jacksoniano se autoproclamó en 1844 "la democracia norteamericana". Aun las sociedades de Demócratas Fraternales, en el interior del cartismo británico de definición socialista y cuyos dirigentes fueron influidos por Federico Engels, no se definían como republicanas. En 1844 Engels distinguía el momento presente, en que el proletariado tenía un papel protagónico, de la revolución francesa, en que el enfrentamiento era entre democracia y feudalismo. Preveía que Inglaterra se encaminaba hacia la democracia social, fase de transición hacia el socialismo, "un principio que supera la política". ciación, con el objetivo prioritario de la unidad o la independencia nacional. ${ }^{32}$

Como en otros estados hispanoamericanos, en Chile fue muy fuerte el impacto de la Revolución de Febrero, de lo que da cuenta su reconocimiento por el presidente Bulnes y el hecho de que, desde el teatro, atronaran los acordes de La Marsellesa. Pasado el entusiasmo inicial, mantuvieron su adhesión un grupo de jóvenes liberales y seguramente sectores del artesanado. En el caso de los primeros, su oposición al autoritarismo legal y su aspiración a cambios políticos y sociales se habían reforzado ya antes con las lecturas de escritores románticos, de obras de carácter histórico, político y sobre cuestiones sociales. Una influencia muy particular había ejercido la Historia de los girondinos, de Lamartine, reconstrucción de la revolutción francesa en que se opacaban las aristas más duras del periodo jacobino y las

${ }^{32}$ En esa coyuntura crítica abierta en la segunda mitad de los años cuarenta, el discurso democrático republicano e igualitario incluyó un abanico de ideass desde las más estrictamente políticas liberales, hasta las democráticas radicales y las socialistas. Eran republicanas las secciones de la Joven Europa que luchaiban contra el absolutismo. En Francia se proclamaban democráticos los integrantes de la Nueva Montañi, donde florecían corrientes urópicas estaralistas. Aun en el Manifiesto cominista, publicado en alemán en Londres poco antes de que estallara la Revolución de Febrero en París, Marx y Engels recomendaban a los miembros de la Liga de los Comunistas integrarse en los partidos democráticos. Después de derrotadas las revoluciones y en un periodo de reacción, la democracia volvió a ser execrada. Tocqueville, que fuera ministro de Luis Napoleón cuando sus tropas derrotaron a la república de Roma y restauraron el poder papal, afirmaba que democracia y socialismo apare cían ligados en Europa. 
contradicciones con los girondinos. ${ }^{33} \mathrm{La}$ coyuntura europea había influido también sobre los artesanos autodidactas, entre quienes se contaban seguramente algunos veteranos del 48 francés.

El Chile de los años cuarenta vivía un momento de singular brillo intelectual al que aportaron emigrados y exiliados, en su mayoría argentinos. En 1842 había sido creada la Universidad y otros institutos científicos y culturales, funcionaban círculos literarios y aparecieron folletos y periódicos -no siempre destinados a perdurar como lo hizo El Mercurio, en Valparaíso-, en algunos de los cuales se habían difundido textos fourieristas, de Owen, Luis Blanc, Lamennais y otros utopistas.

En 1849 se constituyó en Santiago el club La Reforma, que tomó su nombre del periódico publicado en París por La Nueva Montaña, movimiento de reminiscencias jacobinas. El club no tenía demasiados seguidores fuera de los "quarante huitards" que llegaron a singularizarse con nombres de girondinos y jacobinos franceses, y algunos pipiolos, viejos liberales derrotados en 1830 , sin representación ni cargos. La mayoría pertenecía a las mismas clases que los conservadores y, como había sucedido en 1846, las refriegas electorales o sus algaradas terminaban controladas por las fuerzas represivas.

El factor estimulante del 48 europeo, y en particular de la Revolución de Febrero, operó en Chile en una coyuntura política peculiar. No sólo por las elecciones legislativas de 1849 y la perspectiva de la sucesión presidencial en 1851, sino por la división interior de los conservadores.

\footnotetext{
${ }^{33}$ Vicuña, Girondinos, 1989, pp. 29 y ss.
}

Sin embargo, no era empresa sencilla modificar el estilo político imperante, ni una sociedad tan estratificada en la que la mayoría campesina era controlada por los terratenientes.

\section{Los éxitos del general Bulnes. El control de la aristocracia sobre la sociedad}

Manuel Bulnes, militar victorioso que había buscado reducir el conflicto con los liberales y cuyo estilo llano le había proporcionado popularidad, había obtenido algunos importantes logros. Adelantó la frontera en el sur, consiguió que el nuevo Estado fuera reconocido por España, la paz había permitido cierta expansión económica y las finanzas estaban bajo control. Los conservadores no habían sido efectivamente jaqueados desde 1830 , pese a la oposición pipiola y al régimen centralizador en el sur y en el norte.

Se había abierto una especial coyuntura política cuando el ministro del Interior, Manuel Camilo Vial, cambió la integración del legislativo por los procedimientos muy tradicionales de conformar desde el ministerio las listas de legisladores. No pudo impedir, sin embargo, que fueran elegidos algunos pelucones convertidos en enemigos personales y de línea dura, cuyo líder era el ex ministro Manuel Montt, uno de los emergentes del conservadurismo, modernizador, y que ponía énfasis en la necesidad de una educación extendida como un factor de disciplinamiento de las mayorías.

En su colorido relato, el muy joven liberal Benjamín Vicuña Mackenna describió el entusiasmo de los libcrales ante el resultado electoral, que permitió el ingreso de algunos brillantes diputados 
como José Victorino Lastarria, protagonista, entre otros, de recordados duelos verbales, en particular ante la discusión presupuestal. ${ }^{34}$

$\mathrm{La}$ influencia de esa alianza "progresista" -vialista y liberal- en diputados no iba a perdurar, entre otras cosas, por la prolija obra del nuevo ministerio que volvió al redil a algunos de los disidentes que se unieron a los duros.

La oligarquía terrateniente del Valle Central y sus 20 familias, el gran comercio y en la época de Portales los estanqueros, constituían el corazón del conservadurismo, aunque la estabilidad también era apreciada por sectores más amplios luego de los agitados años veinte. En el campo, donde vivía $80 \%$ de la población, las elecciones y la "política" en general estaban controladas por la autoridad de los terratenientes, por sus mayordomos y capataces dentro del fundo, con sus inquilinos y peones, en tanto autoridades locales controlaban a los otros propietarios y campesinos independientes.

No se habían producido levantamientos significativos del campesinado, las poblaciones indígenas al sur del Bío Bío, aliadas a España durante la colonia, habían sido declaradas chilenas y, aunque avanzada la apropiación de tierras, no se había producido una resistencia colectiva.

La huelga casi de carácter insurreccional de los trabajadores del riquísimo yacimiento de plata de Chañarcillo, en las proximidades de Copiapó, había sido contundentemente reprimida y en la minería del cobre predominaba aún la explotación realizada por un sector de pequeños empresarios chilenos. Salvo alguna huelga de sastres en Santiago, no se habían pro-

${ }^{34}$ Ibid., p. 35. ducido conflictos significativos en la actividad manufacturera. Por lo demás, los gobiernos pelucones no se habían mostrado favorables a la formación de sociedades de artesanos. La que fue organizada por un tipógrafo en 1829 en apoyo a los pelucones había sido disuelta en 1830, y encarcelado su inspirador.

Dos textos diferentes entre sí por el momento en que fueron escritos, por su orientación y hasta por las características personales de sus autores, condenan a los ricos con pujos aristocráticos. En el primero el liberal José Victorino Lastarria, que tendría larga actuación en la política chilena, los trató de manera impiadosa. Describe su división en círculos que se atacaban utilizando la calumnia y la traición, articulados en torno a "la comunidad de intereses, del instinto o de ideas", división que encuentra no sólo en Santiago, sino en las ciudades de todo el país. En su opinión, no querían sino mantener su dominio haciendo algunas reformas, pero como conservadores eran incapaces de realizar cambio sustancial alguno. Transformaba, en cambio, en actor de la regeneración al pueblo, integrado por quienes vivían de su trabajo, excluidos de los círculos de gobierno. ${ }^{35}$

Más punzante sería la descripción de Santiago Arcos en 1852, en la carta a su compañero en la Sociedad de la Igualdad, Francisco Bilbao. Recuerda allí que de 1500000 habitantes de Chile, 1400000 eran pobres. Afirma contundentemente, además, la imposibilidad de generar cambios reales dado el sistema de control sobre los pobres, incluyendo su condición de soldados, $y$

\footnotetext{
${ }^{35}$ Lastarria, "Manuscrito", 1978, pp. 75-78.
} 
mientras dure el inquilinaje en las haciendas, mientras el peón sea esclavo en Chile, como lo era el siervo en Europa en la edad media, mientras exista esa influencia ominosa del patrón sobre las autoridades subalternas, influencia que castiga la pobreza con la esclavatura. ${ }^{36}$

\section{Nace y crece la Sociedad de la Igualdad}

Se atribuye a Santiago Arcos, hijo de un banquero y que regresa de París en 1847 , la iniciativa de crear una asociación política, integrando a artesanos y jóvenes liberales que pertenecían al club La Reforma, como el poeta Eusebio Lillo, Manuel Recabarren, Manuel Guerrero, Francisco Prado y el músico José Zapiola. No sin malicia se ha sugerido que más allá de las convicciones políticas y los cambios en la sociedad que postulaban los jóvenes liberales radicales, no era irrelevante que los artesanos fueran gran parte de los soldados y clases de la Guardia Nacional. ${ }^{37}$

Seguramente el proyecto asociativo de Arcos tenía objetivos más amplios: contar con una fuerza de apoyo de base popular por parte del liberalismo y también modificar la penosa situación de los pobres chilenos. El artesanado y el naciente proletariado habían desempeñado un papel muy importante en Europa. En Chile los artesanos habían adquirido presencia pública en los años cuarenta. Del interés de la influyente İglesia católica da cuenta la creación por fray Andrés García de la Hermandad del Sagrado Corazón, integrada con artesanos y de carácter confesional, distinta a las cofradías. ${ }^{38}$

\footnotetext{
${ }^{36}$ Arcos, "Carta", 1978, p. 85.

${ }^{37}$ Izquierdo, Historia, 1990, t. II, p. 101.

${ }^{38}$ Moreno, Historia, 1986, p. 27.
}

La Sociedad de la Igualdad tuvo desde el comienzo una actitud crítica de la política del gobierno por su desconocimiento de las libertades y su imposición de los gobernantes. Entre sus tres "principios", los Iguales habían proclamado "la soberanía del pueblo como base de toda política".

Disuelto el club La Reforma, algunos de sus integrantes pasaron a formar parte de los Iguales, como lo harían los pipiolos e incluso los vialistas algo más tarde. Aunque la Sociedad de la Igualdad creció al principio lentamente, llegó a tener 3400 adherentes, de los cuales aproximadamente 2000 eran artesanos. El nombre de una mujer, Carmen Rosas, figura en la lista de igualitarios deteniclos al imponerse el Estado de sitio el 7 de noviembre de 1850.39

La Sociedad de la Igualdad constituyó una novedad en Chile por sus objetivos a la vez políticos, laborales y sociales, y por su organización permanente con reuniones quincenales. Se crearon también asociaciones de este tipo en San Felipe, Valparaíso, La Serena y Copiapó, entre otras ciudades.

De todas maneras existían diferencias que se hicieron más evidentes a medida que se pasó de la teoría a la práctica política activa. Hubo discrepancias en cuanto a las prioridades, a la actitud ante la Iglesia y en relación con la estrategia política y las tácticas a emplear. Las divergencias se pusieron de manifiesto cuando El Amigo del Pueblo, primer periódico publicado por los Iguales, dirigido por Recabarren, incluyó un capítulo de Palabras de un creyente, de Lamennais, y posteriormente aparecieron los Boletines del Espiritu, cuya autoría presumiblemente era de Bil-

\footnotetext{
${ }^{39}$ Gazmuri, 48, 1992, p. 80.
} 
bao, integrado a su dirección. Ante la polémica pública generada por la respuesta de la Iglesia, que trascendió las celebraciones religiosas y dio lugar a una serie de artículos publicados en la prensa y a una homilía del obispo de Santiago, fue propuesta la exclusión de Bilbao de la Sociedad de la Igualdad. ${ }^{40}$

Era natural que entre los artesanos predominara la tendencia a priorizar sus problemas, las propuestas para abordarlos y las utopías en materia social, aunque por lo menos un sector de ellos mostró interés por las actividades políticas. Toda la conducta de Arcos, quien en junio se aleja de la Sociedad, hace presumir que había querido constituir una fuerza con objetivos políticos que no coincidieron con el rumbo que tomó la Sociedad a partir de junio. Bilbao, por su parte, consideró que en Chile podía triunfar una revolución. Aunque pudo coincidir en la práctica con las tácticas de pipiolos y vialistas, que desde junio tuvieron la mayoría en la dirección de los Iguales, tanto él como los artesanos que participaron activamente en los sucesos posteriores tenían objetivos que iban más allá de la conquista del gobierno. De todas maneras, no todos los liberales fueron "putschistas" y algunos, como Lastarria, se mostrarían dispuestos a reintegrarse a la actividad política legal. La impaciencia revolucionaria de Bilbao, muy influyente en los Iguales, se combinó con la tendencia insurreccional que, en la tradición pipiola, suponía un alzamiento militar. ${ }^{41}$

En los primeros meses El Amigo del Pueblo, luego sustituido por La Barra, había dado gran importancia a las reivindi-

${ }^{40}$ Ibid, pp. 86-87.

${ }^{41}$ Collier y Sater, Historia, 1998, pp. 102-106. caciones de los artesanos, que se lograrían mediante su unión. Consideraban que no habría una fuerza capaz de oponerse a esos 10000 obreros exigiendo justicia y protección a su clase. Entre sus demandas se destacaba la creación de talleres nacionales en los que el trabajo fuese seguro, mejor retribuido y menos pesado. Reclamaban también que sus hijos pudieran asistir a escuelas financiadas por el Estado.

Uno de los efectos más importantes de esa asociación pacífica sería que el pueblo podría ser guiado en su acción política por la razón y la luz. El empleo de pueblo es un elemento significativo del discurso. Podía suponer que los igualitarios, en cuya dirección fungían dos artesanos, representaban a las mayorías o que fueran portadores de la educación política de las mismas, en la creación de una ciudadanía más extendida. En todo caso, esa intervención del pueblo permitiría imponer gobiernos inclusivos.

El programa de los Iguales planteaba la protección a la industria y a la actividad de los artesanos, la reestructura del sistema impositivo, el mejor trato en la justicia y en los cuarteles de la Guardia Nacional. ${ }^{42}$

En los primeros meses se formularon proyectos para crear escuelas populares gratuitas, montes de piedad, y Bilbao propuso la creación de baños públicos. Una importante labor de los Iguales fue el dictado de cursos y conferencias destinados a la formación intelectual, política y moral del artesanado.

Desde el comienzo los conservadores atacaron duramente a los Iguales, acusándolos de perturbar el orden y los tacharon de pobres y anarquistas -iban a aceptar la primera calificación, para ellos honrosa-

${ }^{42}$ Bilbao, "Sociabilidad", 1941, p. 184. 
y hasta de saint-simonianos practicantes de la comunidad de bienes y de mujeres.

\section{Pasión y muerte}

Desde mediados de 1850 , siendo ya ministro del Interior Augusto Varas, partidario del entonces candidato presidencial Manuel Montt, el hostigamiento físico se sumó a la diatriba. Por su parte los Iguales realizaban reuniones cada vez más numerosas en la casona ubicada en San Antonio y Las Monjitas y los participantes comenzaron a manifestarse en la Alameda.

Lo que aconteció en adelante tuvo visos de fatalidad. Una situación en que los contrincantes se fueron enardeciendo fue pautada por una sucesión de hechos que culminarían en el frustrado levantamiento del 20 de abril de 1851 .

El 19 de agosto, luego de finalizada una reunión tumultuosa, una banda en que participaron conocidos matones, pero cuya dirección llegaba a la oficialidad de la Guardia Nacional, golpeó a algunos Iguales que permanecían en el local. A partir de ese momento se iban a celebrar las reuniones más numerosas, que en algún caso congregaron a 1500 enfervorizados asistentes y que obligaron a utilizar un local más amplio.

Cuando el Senado discutía estos hechos, el 13 de septiembre en San Felipe, localidad donde la tensión se hizo particularmente crítica, el gobierno denunció que un piquete de tropa había encontrado en el equipaje de dos destacados dirigentes igualitarios un cajón con balas.

Proclamada la candidatura de Montt el 20 de octubre de 1850, el 28 la Sociedad emitió un duro comunicado en su contra porque representa los estados de sitio, las deportaciones, los destierros, los tribunales militares, la corrupción judicial, el asesinato del pueblo, el tormento en los procedimientos de la justicia criminal, la abolición de la ley de imprenta, la usura, la represión en todos los casos que puede extenderse, con perjuicio de los intereses nacionales y especialmente con respecto al derecho de asociación. ${ }^{43}$

La catilinaria apuntaba al gobierno, en cuyo ministerio se había reforzado la influencia monttovarista, pero el texto constituye también, a contrario sensu, toda una base programática opositora esencialmente política. La oposición denunció públicamente que la manipulación desde el gobierno impediría la libre expresión del pueblo.

Cuando el 5 de diciembre se produjo un verdadero motín en San Felipe, donde la situación no había hecho sino agravarse, el gobierno impuso el estado de sitio en Santiago y Aconcagua. A continuación se desató la represión militar y la ola de detenciones. Fueron desterrados la mayoría de los dirigentes igualitarios. ${ }^{44}$ Bilbao pasó a la clandestinidad y la Sociedad quedó extremadamente debilitada.

En los grupos que se fueron reconstituyendo de manera clandestina iba a predominar una desesperada tendencia insurreccional, y el 12 de abril en una reunión del llamado Club Lepelletier se acordó el levantamiento santiaguino para el día 20.

En "La revolución en Chile y los mensajes del proscripto", escrito en el exilio en 1853 , Bilbao confrontaría la visión de los igualitarios - por lo menos de aquellos

${ }^{43}$ López, Salvación, 1995, p. 55.

${ }^{44}$ Gazmuri, 48, 1992, pp. 101-103. 
que compartían su perspectiva sobre el mundo- con la de los liberales parlamentarios y en particular la de Lastarria, duro crítico a posteriori del levantamiento. Bilbao resumía las diferencias en el hecho de que los parlamentarios no habían visto "al pueblo, a la igualdad, sino como un instrumento", mientras los Iguales lo habían mirado "como fin, y a las Cámaras como instrumentos". ${ }^{45}$ Sin duda su afirmación es atinada, dado que la finalidad de los pipiolos era puramente política. Los insurgentes recurrieron a una táctica que no empleaban por primera vez: el levantamiento militar, en este caso del regimiento Valdivia acantonado en la capital.

Bulnes encabezó la represión de la insurgencia, a la que se unió una parte del regimiento Valdivia, cuyo comandante, Pedro Urriola, murió entonces. ${ }^{46}$ Junto a Bilbao se batieron gentes del pueblo, aproximadamente unas 500 personas, de las cuales sólo eran 50 artesanos, mientras otros de éstos se presentaron a la convocatoria de la Guardia Nacional. ${ }^{47}$

Pocos meses más tarde también fue sofocada la revuelta en Valparaíso donde fue detenido, entre otros, Bartolomé Mitre. La revolución igualitaria triunfó durante un corto lapso en La Serena y según Francisco Encina la junta que se constituyó, además del regimiento Yungay, "reclutó a unos 300 o 400 changos, jornaleros urbanos y trabajadores de las fundiciones", atribuyendo a la que califica como de "revolución popular" más entusiasmo que disciplina. Según su relato "la revolución procuró movilizar los elementos de disolución que dormitan en el

45 Bilbao, Obras, 1897-1898, t. JII, p. 13.

${ }^{46}$ Romero, Sociedad, 1978, pp. 66-70.

${ }^{47}$ Gazmuri, 48, 1992, pp. 107-108. fondo de todo pueblo, contenidos por el peso de la organización política y social, desde el obrero y el campesino hasta el aventurero y el bandido". ${ }^{48}$ Queda aquí bien expresada la percepción conservadora sobre el movimiento en la región, el romanticismo de sus jóvenes dirigentes y el riesgo advertido por la "gente decente", que tan bien expresó el argentino Frías. El ejército comandado personalmente por Bulnes, que recién había finalizado sus dos periodos presidenciales, dominaría también el levantamiento de Concepción encabezado por el general conservador José María Cruz, y que procuró ser encauzado por liberales entre quienes se contaba el veterano pipiolo Pedro Félix Vicuña. Cruz fue derrotado pese a las fuertes resistencias regionales a la centralización santiagueña, lo que no excluyó la fidelidad al gobierno por parte de hacendados y también desde las ciudades. Además de las fuerzas armadas de la región que comandaba, Cruz reclutó campesinos de manera tradicional y contó con la adhesión de lanceros indígenas, aunque otros respondieron al gobierno siguiendo a su cacique. ${ }^{49}$

Con más pena que gloria finalizaba esa experiencia cuya mayor originalidad provino de la breve alianza entre políticos liberales radicales, utópicos revolucionarios y artesanos enmarcados temporalmente en una organización.

\section{La revolución pacífica de Santiago Arcos}

La "revolución" de abril del 51 no contó con la participación de Arcos. En la men-

${ }^{48}$ Encina, Historia, s. a., t. Xxrv, p. 46.

${ }^{49}$ lbid., pp. 167-191. 
cionada carta a Bilbao, publicada durante su residencia en la provincia argentina de Cuyo, al referirse a la democracia le recordaba posiciones compartidas:

\begin{abstract}
Bien se ve que usted aprueba estas ideas que nos harían adoptar la democracia pura, es decir, la administración de cada subdivisión territorial por su representación -su municipalidad-, al menos así pensábamos en 1850 , cuando nuestro pensamiento fue sofocado por la precipitación por llegar al mando. ${ }^{\text {so }}$
\end{abstract}

Si bien sintética, es ilustrativa su caracterización del episodio vivido por los Iguales y no carece de un dejo de reproche a su antiguo compañero.

50 Bilbao, "Apuntes", 1941, pp. 175-176. Recuerda aquí Bilbao episodios de su vida y registra brevemente la revolución del 20 de abril. Relata que apenas llegó a Perú procuró organizar allí una sociedad de jóvenes con el fin de lograr la abolición de la esclavitud y fortalecer el racionalismo. El texto busca resaltar su acción revolucionaria en el momento del triunfo del general Castilla, y su papel en la abolición de la esclavitud y la mita, que le deparó el odio de los propietarios. Luego de una dura polémica sobre la libertad de culcos, tras la cual sería excomulgado, y en medio de una agitación en su contra promovida por la Iglesia, marcharía a Francia, para lo cual los amigos del gobierno pagaron su pasaje. Allí escribiría su texto más famoso, El Congreso americano, en el que convoca a la unión de los hispanoamericanos en momentos en que Nicaragua era intervenida por el estadunidense William Walker. Bilbao, que puede ser considerado uno de los protolatinoamericanistas, moriría finalmente en Buenos Aires, luego de una no desdeñable participación durante los años que transcurren hasta el triunfo de Mitre. Profesó el federalismo, aunque desilusionado de las actitudes de Urquiza. En esa etapa de su vida desempeñó un importante papel en la masonería, y en sus últimos años se pronunció contra la intervención napoleónica en México.
Rechaza la posibilidad de intentar una nueva revolución, a la que apuesta Bilbao exiliado en Perú.

Arcos sostenía no sin fundamento que, de haber triunfado Cruz, la situación no habría tenido, a los pocos meses, un desenlace distinto, dado que -en su opiniónno existían diferencias sustanciales entre liberales y conservadores del mismo origen social. En todo caso -afirmaba- unos y otros diferían sólo en la medida en que los primeros acrecentaban sus partidarios con quienes aspiraban a disfrutar los cargos de gobierno, mientras los conservadores ya los ejercían. Expresa que, como todo partido, el pelucón tenía "su hez", constituida por hombres de acción que vivían del Estado, sin más patrimonio que las "arcas nacionales, o empresas asalariadas, o privilegios injustificables".

Para fundamentar sus tesis y no sin perspicacia, acota que el escaso apoyo recibido por la revolución se debió al poco entusiasmo que despertaba la consigna "libertad es sufragio inteligente" entre los pobres, para quienes no había diferencia entre pelear junto al patrón Bulnes o el patrón Cruz.

Confía en todo caso en un partido nuevo, "el partido democrático-republicano", mencionando como posibles dirigentes a los liberales radicales con quienes había fundado la Sociedad de la Igualdad.

Proponía, en cambio, la realización de una revolución pacífica. En la lista de libertades y derechos a establecer después de su triunfo se contaban los clásicos del liberalismo político de la época. Entre las obligaciones de la república enumeró las propias de una democracia social: proporcionar educación, trabajo, protección al huérfano, al enfermo y al anciano, propiciar la rehabilitación moral del delin- 
cuente mediante la educación y otorgar con amplitud la ciudadanía a los extranjeros. Sea por adhesión al liberalismo económico o porque su experiencia con los artesanos había fracasado, no los menciona.

Propone como eje de su proyecto dividir las grandes propiedades, así como el ganado y las herramientas, no sólo en las regiones poco pobladas -adquiriéndolas allí a los indios-, sino en el Valle Central, reservando una parte a los propietarios y pagándoles con títulos de deuda pública el valor del resto. Sus beneficiarios habían de ser campesinos chilenos e inmigrantes. Más que la invocación a la democracia y el derecho al sufragio creía que:

El pobre tomará una parte activa cuando la república le ofrezca terrenos, ganado, instrumentos de labranza, en una palabra, cuando la república le ofrezca hacerlo rico y dado ese primer paso le prometa hacerlo guardián de sus intereses dándole una parte de influencia en el gobierno. Cuando el pobre sepa que la victoria no es sólo un hecho de armas glorioso para tal o cual general, sino la aprobación de un sistema político que lo hace hombre, que lo enriquece.

En realidad, esta perspectiva utópica no difería demasiado de las expuestas, en torno al medio siglo, por liberales de una nueva generación en gran parte de Hispanoamérica.

Arcos fue un convencido liberal en la economía y en el campo político, sin perjuicio del papel reparador que asignaba al Estado. Consideró posible acercar a su proyecto a los extranjeros cuya influencia consigna -refiriéndose seguramente a quienes manejan gran parte de la economía-, asegurándoles libertad de comercio, religiosa y paz. Creyó que podría atraerse al bajo clero y, en cierta medida, también a los hacendados, lo que bien mirado constituye uno de los aspectos más utópicos de su proyecto.

Tal vez deba atribuirse a viejos radicalismos la consigna "pan y libertad" cue había sido el grito de los descamisados europeos y que en su opinión atraería a los inmigrantes. En todo caso no estuvo descaminado en cuanto a la posibilidad de que llegaran a Chile quienes habían sido vencidos en las revoluciones europeas, como parte de esa inmigración que era uno de los ejes de su proyecto. ${ }^{51}$

\section{De cómo cambian los hombres: el juicio lapidario de un exiliado argentino y el triunfo temporal conservador}

Félix Frías consideró que la derrota liberal constituía "el triunfo de la causa de la civilización en Chile". Declaraba que la victoria del gobierno en ese país no era la de un partido sobre otro, sino la de todos los chilenos contra la "violencia y la revolución". Y sin demasiada originalidad afirmaba:

$Y$ no necesitamos venir a Francia y recordar los nombres de esos bandidos execrables

${ }^{51}$ Arcos, "Carta", 1978, pp. 79-99. Todos los fragmentos citados pertenecen a este documento. Durante la "revolución" de abril del 51, Arcos, desterrado, estaba en California, adonde habían emigrado chilenos seducidos por el boom del oro. En 1855 Arcus llegó a Buenos Aires y apoyó a Mitre, antiguo igual e impulsor del liberalismo político. Retornaría a Francia en 1864, y luego de la revolución española que derrocó a Isabel II fue inexitoso candidato a las Cortes. Su vida terminó en París en 1874 a consecuencia de un balazo con el que, ya enfermo, logró abreviar una dolorosa agonía. 
que se llaman Marat, Saint-Just y Robespierre, para comprender en favor de quiénes trabajan los turbulentos demagogos [Y añadíal, lo que me ha parecido sumamente alarmante en las últimas agitaciones de Chile es la tendencia socialista del espíritu revolucionario.

Ese socialismo habría concedido a los rotos, "fanatizados por torpes esperanzas, el derecho de robar y matar".

Frías juzgaba duramente la ligereza que denunciaba en los jóvenes imitadores de la experiencia francesa. Condenaba el levantamiento liberal particularmente porque había subvertido a los rotos e incluso a los indios. En Chile había existido -pensaba - toda la libertad posible y el orden imprescindible en esos nuevos estados, que podían pasar de la anarquía a una tiranía como la impuesta por Rosas.

Haciendo una vez más una comparación absurda, añade:

Contra esa bandera roja [...] es contra la que han luchado los argentinos. Rosas no es otra cosa que el socialismo en el poder; lo que en Francia habían amenazado las bárbaras teorías [Y sentencia], el orden debe ser la regla suprema de todas las libertades políticas [...] no podemos ser tan demócratas como los norteamericanos; es preciso que seamos tan liberales como podremos ser libres. ${ }^{52}$

Poco diferían a esa altura sus opiniones de las que expondría Rosas, exiliado en Inglaterra, ante la organización de la Primera Internacional.

Lo que he visto y veo [expresaba] es insolencia de la plebe, licencia escandalosa y sin

52 Frías, "Triunfo", 1995, pp. 152-153. freno en los agitadores; concesiones y más concesiones sin équilibrarlas; tumultos, reuniones, huelgas por días, semanas y aun más en algunos lugares.

Para enfrentar una situación que lo alarmaba llamaría a los gobiernos a constituir una Santa Alianza y convocaba al papa a encabezar un gobierno universal. ${ }^{53}$

Si había fracasado la revolución violenta, tampoco se convirtió en realidad la revolución pacífica de Arcos. No obstante, todo parece indicar que este episodio, así como el bagaje de ideas que difundió, no pasó sin dejar huellas en la historia de Chile.

A partir de 1853, en que fue organizada y reprimida en Santiago la Sociedad Tipográfica, nacerían las sociedades de artesanos, pero ya sin el carácter político de la Sociedad de la Igualdad. Las sociedades de resistencia y las mancomunales, que se levantarían en las últimas décadas del siglo XIX, agruparon a mineros, obreros urbanos y asalariados de los servicios.

Pocos años habían pasado cuando se produjo un nuevo levantamiento liberal, con menor contenido en el plano social, y en 1863 nacía el Partido Radical, decididamente laico y que, aunque en condiciones distintas, había sido más afín a los liberales en la versión juvenil.

Pasarían décadas antes de que, en distintas circunstancias y luego de intentos fallidos de crear partidos socialistas e incluso uno con el nombre de Bilbao, en 1889 se constituyera el Partido Democrático, que buscó articular al ya experimentado movimiento obrero con su propuesta política democratizadora. Pero se trata ya de otra época con diferentes actores.

${ }^{53}$ Lynch, Juan, 1984, p. 329. 


\section{UNA TEMPRANA CONTROVERSIA ENTRE DEMOCRACIA FORMAL y SUSTANCIAL EN NUEVA GRANADA}

Del singular proceso neogranadino entre los años 1849 y 1854 , seguido a través de la producción historiográfica y documentos publicados sobre la época, nos detendremos en la interesante oposición en torno a democracia en que contrastaron muy tempranamente dos versiones, la formal y la sustancial.

\section{Democratismo, utopismo socialista e impacto de la revolución del 48}

Aunque desde distintas tiendas se marcó la influencia del pensamiento utopista y de la Revolución de Febrero, es elocuente la visión de Rafael Núñez, dos veces presidente de Colombia en los años ochenta, y que de liberal pasó a la jefatura del Partido Nacional que reunió sectores del liberalismo y el conservadurismo. Recordaría Núñez que "el movimiento político liberal que se inició en 1848 y 1849 fue en gran parte producto indirecto de la revolución que instauró en Francia, en el primero de dichos años, el régimen republicano". Desde 1849, añadía, se produjo un verdadero alud de "utopías y paradojas francesas". Destaca la influencia de Lamartine sobre una nueva generación de literatos y agrega que los interesados en la economía habían adoptado las ideas de Luis Blanc, Prudhon y otros que, siguiendo la interpretación lamartiniana de la revolución francesa, "encontraban más de su gusto el demagógico ejemplo de los antiguos jacobinos." 54

$$
\$ 4 \text { Vargas, Colombia, 1972, p. } 24 .
$$

No estuvo errado Núñez en cuanto a valorar la influencia europea de ese fondo de ideas y su impulso para los grandes cambios que se realizaron a mediados de siglo en su país, aun cuando algunas de las esperanzas puestas en la transformación de la sociedad resultaran frustradas. Es también aguda su distinción respecto a las influencias ideológicas sobre las fracciones liberales: los llamados gólgotas, de discurso socializante, y los democráticos, cuyas prácticas de movilización popular por momentos evocan el "sansculotismo" parisino.

El detonante francés adquiere rasgos peculiares en Nueva Granada en el medio siglo, periodo considerado como el verdaclero fin de la colonia que había pervivido después de la independencia. Los hombres de ruana movilizados por la Sociedad Democrática bogotana, por ejemplo, fueron decisivos para la imposición de un presidente liberal en 1849. Esta sociedad y otras que se levantaron en distintas ciudades influyeron para imponer algunas de las reformas más importantes, como la abolición de la esclavitud, el sufragio "universal" y para establecer el impuesto directo en sustitución de múltiples y viejos gravámenes.

Después de siglos de colonia, la independencia no se tradujo, naturalmente, en Hispanoamérica en su aislamiento respecto del mercado mundial en conformación, ni del mundo de las ideas occidentales y sus avatares políticos al que era particularmente sensible la población urbana. Muy diferente, en cambio, era la visión del mundo de las mayorías campesinas, heterogéneas por su composición étnica, social y aun regionalmente insertas en las redes de dependencia personal en la hacienda y en poblados rurales, mientras pervivían las comunidades indígenas con sus imaginarios tradicionales. 
Las sociedades democráticas: su fisonomía especifica

La influencia del artesanado era antigua y las luchas populares urbanas no comenzaban entonces en Nueva Granada: baste recordar la acción de los Comuneros del Socorro a fines del siglo XVIII.

En nombre de los artesanos de Cartagena había sido exaltada en 1836 su capacidad para autodeterminarse, en momentos en que apoyaban la candidatura presidencial del general José María Obando. Éste contaba con el apoyo del entonces presidente general Francisco de Paula Santander, definido como liberal que había encabezado la oposición a Bolívar y era admirador del utilitarista Jeremías Bentham. Se sostuvo en esa ocasión que "nacidos libres por la naturaleza y por nuestras instituciones" estarían de parte "de la causa popular", y que habiendo desaparecido el sistema español, "el curso de las cosas y el progreso de la civilización" los había hecho conocer sus derechos y deberes. ${ }^{55}$

La autonomía y la autodeterminación de los artesanos serían destacados en otro momento de este proceso por El Demócrata de Bogotá en 1850. El periodista se congratulaba de los derechos adquiridos $y$ de que los artesanos empezaban a "tomar parte en la discusión política". Añadía que no eran el "brazo que ejecuta ciegamente la voluntad ajena sino un cuerpo compacto, homogéneo que siente y juzga por sí mismo y que obra en virtud de voluntades propias". ${ }^{56}$

"5s Posada, "Alternancia", 1999, p. 175.

56 "La expresión de los artesanos", El Demócrata, núm. 4, 2 de junio de 1950, Bogotá, citado en Gutiérrez, "Literatura", 1999, p. 188.
La Sociedad Democrática de Bogotá era fruto de la transformación de la Sociedad de Artesanos, fundada por el sastre Ambrosio López en 1847. López renegaría del rumbo que tomó la sociedad a partir de 1848 y acabaría expulsado de la misma. ${ }^{57}$ Las sociedades democráticas iban a distinguirse de las asociaciones corporativas y solidaristas entre las que figuraron las de tipo confesional, propiciadas por los conservadores y por la Iglesia, como la Sociedad Filotémica o la del Niño Dios. Difirieron también de las sociedades republicanas, en las que se integraron los jóvenes liberales de discurso socializante humanista, y cuya invocación al mártir del Calvario y al cristianismo primitivo dio lugar a que, con sarcasmo, los conservadores los calificaran de gólgotas. ${ }^{58}$

Como en el caso de Chile, la denominación de democráticas podía evocar entonces a las sociedades parisinas del mismo nombre, a la vienesa -mediante la cual obreros, estudiantes, artistas e intelectuales habían obligado en 1848 a convocar una Constituyente elegida mediante sufragio universal-y a las Democráticas Fraternales británicas.

El empleo de una terminología radical se ejemplifica en el uso de la palabra proletario, publicado en un artículo en fe-

57 Vargas, Colombia, 1972, pp. 35 y 40. En dos folletos López condenaría los hechos ocurridos a partir del 7 de marzo de 1849 , cuando los democráticos impusieron la presidencia liberal de Hilario López.

${ }^{58}$ Las sociedades de artesanos en el periodo han sido abordadas, entre otros autores, por Jaramillo, "Sociedades", 1974. Del mismo autor, "Etapas", 1985, pp. 39-44; Tirado, "Colombia", 1985, pp. 118-124; Escobar, Revolución, 1990. La autora trata específicamente el tema de la relación entre liberales $\mathrm{y}$ artesanos. 
brero de 1849 en El Alacrán-periódico que se caracterizó como comunista- por dos jóvenes intelectuales originarios de Cartagena, ciudad más vinculada con los vientos del mundo que Bogotá, y activo centro intelectual. Se denunciaban allí como enemigas "las clases ricas, los inicuos opresores, los endurecidos monopolistas y los agiotistas protervos". Más intimidante podía resultar la afirmación de que, sabiendo los ricos que habían usurpado "a la clase proletaria", temían verse desalojados de sus "opulentos palacios" y del disfrute de otros privilegios. A lo que se agregaba que "las masas conocerán al fin que unos pocos hombres están gozando solos de los bienes y las dichas que el Supremo Hacedor" dispuso para todos, porque había quienes tomaban en sus manos la causa de los "oprimidos". 59

Tanto el texto como el comunismo que inspiraba al periódico provocaron la reacción de los conservadores. Los liberales, expusieran o no un discurso socializante, necesitaban en 1849 la participación de los hombres de ruana. El 7 de marzo, éstos, con cintas rojas en sus sombreros, reunidos en la plaza imponían a los legisladores la presidencia del general liberal José Hilario López, cuando ninguno de los tres candidatos había obtenido en las urnas la mayoría requerida.

Las sociedades democráticas, única organización urbana capaz de movilizar un sector popular, continuarían siendo decisivas para imponer leyes promovidas por los liberales. El 7 de agosto de 1850 , incluso, el presidente López y algunos de sus ministros participarían en una de sus

59 Joaquín Posada y Fernán Piñeros, El Alacrán, 8 de febrero de 1849 , citados en Vargas, Colombia, 1972, pp. 24-25. reuniones en Bogotá, donde se sucedieron discursos radicales. ${ }^{60}$

\section{El contrapunteo en torno a democracia y su relación con la propiedad. Liberalismo versus protección del trabajo}

Un sector de los liberales en Nueva Granada quiso limitar a los propietarios la representación y el ejercicio del sufragio atribuyéndoles virtudes cívicas. Florentino González, enfrentado con los democráti$\cos$, defendió la democracia ilustrada e inteligente, oponiéndola a "la democracia bárbara en que el proletarismo y la ignorancia" ahogan "los gérmenes de la felicidad", que sólo traería "la pobreza, la degradación y el envilecimiento de la especie humana". El término proletarismo es usado aquí con un sentido muy diferente del que le daba Echeverría, de tono lerouxiano, percibido como la condición de explotado, que el argentino buscaba superar. González lo utiliza en forma despectiva, relacionándolo con la ignorancia y para descalificar a la democracia "bárbara". Declara su oposición a los "niveladores" y su igualitarismo (tal vez evocando el uso del término durante la primera de las revoluciones inglesas y el igualitarismo de los sans culotte en 1793 y 1794) y plantea en cambio elevar la clase pobre al nivel de la ilustrada y rica. ${ }^{61}$

El herrero Miguel de León reconocía, en cambio, que el bajo pueblo estaba acostumbrado a seguir a ricos y nobles cuando eventualmente era convocado a designar electores, sufragando "ciegamen-

(*) Vargas, Colombia, 1972, pp. 38-39.

(1) Véase Florentino González Martínez en Gutiérrez, "Literatura", 1999, p. 185. 
te por la lista que le presenta la clase elevada". No obstante, resaltaba sus virtudes republicanas y cristianas y presentaba a los artesanos (mayoritarios por lo menos en las ciudades, aunque minoritarios en relación con la población total) como una especie de modelo ciudadano. ${ }^{62}$

Para los democráticos, la democracia radicaba no sólo en la incorporación de las mayorías a la ciudadanía, sino en la posibilidad de imponer, por encima del derecho positivo, $y$ aun desconociendo el orden legal, los derechos naturales y la justicia. $^{63}$

Un sector del liberalismo neogranadino predominante durante la presidencia de López, que incluyó a gólgotas y democráticos, impuso el sufragio de los hombres mayores. Pesaban, sin duda, sus convicciones democráticas, necesitaban la presión de ese pueblo para reformar el sistema político, para ampliar el acceso a los altos cargos de gobierno, hasta entonces en manos de las grandes familias y de militares que habían luchado por la independencia.

Los liberales impulsaron durante el gobierno de López el nuevo texto constitucional que finalmente entró en vigencia en 1854. Los hechos demostrarían que, pese a la alternancia partidaria previa y posterior, ni conservadores ni liberales de ningún tipo se sujetarían a las normas legales en su lucha por el poder.

Si bien hasta 1853 no se enfrentaron abiertamente democráticos con los gólgotas y otras fracciones del liberalismo,

${ }^{62}$ El Demócrata, citado en Gutiérrez, "Noticias", 1977, p. 184.

${ }^{63} \mathrm{El}$ punto ha sido tratado con singular solvencia por Gutiérrez Sanín, aunque no todas sus conclusiones sean compartibles. había contradicciones entre ellos ya desde 1850. Ambos sectores eran partidarios de la ampliación del sufragio y ambos impusieron la abolición de la esclavitud en nombre de los derechos humanos y la justicia. La medida suponía la violación del derecho positivo, cosa que los liberales estaban dispuestos a hacer. La independencia, por lo demás, había supuesto el supremo desconocimiento del derecho colonial, y ni patriotas ni realistas habían respetado el derecho de propiedad nacido en la colonia, lo que tampoco hicieron durante las guerras civiles los liberales ni los conservadores, siempre que se tratara, por supuesto, de la propiedad del enemigo.

Algo muy diferente ocurrió cuando, a partir del desconocimiento de la propiedad esclavista, el discurso de algunos democráticos se fue deslizando hacia el cuestionamiento de la propiedad privada en sí misma. Con fundamentos de tipo ético, al monopolio de la propiedad y al egoísmo de los ricos se les atribuyeron los males que sufrían los pobres.

La propiedad privada también acabaría siendo cuestionada en el discurso de algunos democráticos e incluso propugnada la "comunidad cristiana y filosófica de los bienes de la tierra", cuando, según denunciaron, eran despojados los pobres y los liberales al dividirse los ejidos de Cali. ${ }^{64}$

64 "Justicia" en El Pensamiento Popular, núm. 9, 15 de mayo de 1852 , Cali, citado en Gutiérrez, "Literatura", 1999, p. 192. La oposición proteccionismoliberalismo no fue puramente teórica. Lass políticas adoptadas dependieron de acuerdos políticos, de la necesidad de atender déficit fiscales y de las propias características de la producción del país. Iin México, por ejemplo, que contaba con la industria fabril y manufacturera más desarrolladas de Hispanoamérica, el Congreso de mayoría liberal impuso en 1856 una política intermedia entre proteccionismo y liberalis- 
El tema no era menor en Nueva Granada ni en el resto de Hispanoamérica. La consolidación de la propiedad de las tierras ejidales, las fiscales poseídas sin títulos, las eclesiásticas desamortizadas y las de las comunidades indígenas fue realizada en perjuicio de las mayorías. Aunque en algunos casos se beneficiaron sectores de pequeños y medianos productores, la consolidación de la propiedad contribuyó a la conformación de la gran hacienda, la estancia y la plantación. La mayor parte de la tierra fue vendida a bajo precio, pagada con títulos de deuda pública adquiridos generalmente depreciados, para proporcionar ingresos a un fisco deficitario. En Nueva Granada, donde la venta de las tierras eclesiásticas desamortizadas fue más tardía, en esta época la supresión de los resguardos indígenas no convirtió, por cierto, a los indios en pequeños propietarios con mentalidad capitalista.

El derecho al trabajo chocaba entonces con el mundo de ideas de los liberales, que podían hasta crear escuelas artesanales con el nombre de talleres nacionales. En cambio, eran irreductibles en cuanto a la liberalización del comercio exterior y el aflujo de mercancías y capitales, que consideraban fundamentales para lograr el progreso. ${ }^{65}$

mo. En Argentina, durante la crisis de los años sesenta, serían los productores de lana los que demandarían protección a la industria nacional. En todos los casos los impuestos aduaneros fueron una de las principales fuentes de ingreso, de modo que, antes de que constituyeran un objetivo buscado, su elevación iba a operar como protección a la industria naciente.

${ }^{65}$ Reclamos de protección a las producciones artesanales se produjeron en Hispanoamérica en diferentes etapas ante la competencia industrial. Si en el caso de México un sector de artesanos fue afectado
Por una suma de razones y aun de sinrazones los democráticos apoyaron la candidatura presidencial del general Obando en 1853, contra el candidato de los gólgotas. El triunfo electoral de este caudillo militar, en comicios en que se abstuvieron los conservadores, revertía su anterior derrota electoral y también la derrota militar en 1842. No resulta ocioso recordar que en 1836 Obando había contado con el apoyo de sectores de artesanos.

A decir por lo expresado años más tarde por el destacado liberal Miguel Samper, los artesanos odiaban a los gólgotas. Afirmó que "en muchos de los obreros de ciertos oficios [...] predomina una fuerte antipatía contra las clases más acomodadas [...] y un odio reconcentrado contra todo lo que se llama gólgota o radical", cuyo partido se oponía a "las ideas de protección a favor de los artefactos nacionales" ${ }^{66}$ Seguramente en 1853 los democráticos habían votado contra el sector civilista y gólgota del liberalismo al cual reprochaban haber desatendido esta demanda concreta.

\section{Hacia la dictadura}

Sin detenernos en el proceso político, vale la pena mencionar algunos de los hechos singularmente significativos del breve gobierno de Obando.

por la industria nacional que creció apoyada por el Banco de Avío creado en 1832, en el resto de la región la competencia provenía de los productos importados. No es irrelevante que los igualitarios chilenos demandaran la protección industrial, ni que algo más tarde los artesanos peruanos se opusieran a la importación de muebles.

${ }^{66}$ Citado en Vargas, Colombia, 1972, p. 57. 
Conservadores y gólgotas conformaron desde el inicio de su mandato una oposición que no le daría tregua y que fue más eficaz al ganar los comicios legislativos y para los gobiernos locales.

Sin perjuicio de las decisivas condicionantes internas, pesaba entonces el clima conservador de la época. J. M. Restrepo recuerda la esperanza de que la proclamación del imperio por Napoleón III favoreciera una reacción contra las "utopías impracticables" y "doctrinas exageradas de todo género" copiadas de Francia. ${ }^{67}$

El texto constitucional que juró Obando y entró en vigencia el 1 de enero de 1854 no conformó enteramente a nadie. Según el diputado panameño Julio Arosemena, tanto conservadores como liberales gólgotas esperaban imponer sus concepciones en cuanto la situación política los favoreciera.

Tampoco satisfizo a las tendencias descentralizadoras, federalistas, tradicionalmente sustentadas por los liberales. Pese a lo escueto, resulta ilustrativo del clima de la época el relato de Arosemena. Era en Panamá tal vez más fuerte que en ningún otro lado la tendencia a constituir un Estado prácticamente independiente que formaría parte de una muy laxa confederación, cuya cabeza se radicaría en la lejana Bogotá. El autor fue severo crítico de la limitación del sistema municipal y de otros aspectos del texto constitucional. ${ }^{68}$

En el discurso conservador la Constitución era contraria "a los usos, costumbres y hábitos" del pueblo, y obra de "empíricos e ignorantes que copiaban a Proudhon, Luis Blanc, Girardin...". 69 Tan-

\footnotetext{
${ }^{67}$ Restrepo, Diario, transcrito en ibid., p. 27.

68 Arosemena, Panamá, 1981, pp. 53-92.

6) Restrepo, Diario, transcrito en Vargas, Colombia, 1972, p. 64 .
}

to o más urticantes fueron las medidas secularizadoras, incluidas la independencia de la Iglesia en relación con el Estado y el matrimonio civil, aunque no se prohibiera el religioso.

El presidente había jurado un texto constitucional del que no aprobaba, entre otras cosas, las limitaciones impuestas al poder ejecutivo. Los democráticos rechazaban la limitación de las facultades del único poder sobre el cual podían influir.

En pocos meses Obando sería cercado por el poder legislativo, por gobiernos regionales y por la conservadora Corte de Justicia. Crecientemente los apoyos principales del gobierno quedarían reducidos a las sociedades democráticas -cuya movilización cotidiana no contribuía a la calma- y al ejército, que en la región comandaba el general Juan José de Melo. Obando frenó el proyecto gólgota de reducir o aun suprimir el ejército permanente y el generalato, y amenazó con designar a Melo en la cartera de guerra.

El presidente no quería y no podía gobernar contra las grandes fuerzas económicas. Ya durante la campaña electoral y el mismo día de su asunción en la catedral procuró tranquilizar a los propietarios, despegándose del discurso socializante de los gólgotas y del radicalismo democrático, y garantizando el respeto de la propiedad. ${ }^{70}$ Los "guaches rojos" no sentían, obviamente, el mismo respeto por algo de lo que carecían, y en lo inmediato reivindicaban el derecho al trabajo que asociaban a la protección de la industria artesanal.

Algo tan visible como la vestimenta se convirtió en un signo de adhesión política y de pertenencia de clase. En las calles de Bogotá se enfrentaban hombres de ruana

\footnotetext{
70) Vargas, Colombia, 1972, pp. 66-67.
} 
y alpargatas, por un lado, y "cachacos" de vestimenta europea por otro. El odio hacia los gólgotas y desde luego a los conservadores se extendía a todos los ricos, y el discurso igualitario prendía en las mayorías urbanas.

La controversia argumental contra los democráticos de Bogotá incluyó su calificación de oligarquía provincial. Una de las muchas acusaciones en su contra denunciaba que los artesanos en la calle pretendían ejercer por sí mismos las facultades reservadas al pueblo. Una crítica fuerte desde tiendas liberales moderadas contra el clasismo democrático giró en torno a democracia misma. En opinión de éstos, la democracia no admitía "la clasificación de los hombres en hombres de ruana y hombres de casaca", porque entonces desaparecía la igualdad. ${ }^{71}$ Tal vez sin advertirlo, los bandos enfrentados estaban empleando argumentos que atravesaron toda la historia. En el fondo se trataba de dos concepciones opuestas en torno al principio de igualdad reconocido como básico de la democracia: para unos consistía esencialmente en la igualdad de los hombres ante la ley, para otros dicha igualdad debía partir de la reparación de las injusticias que sufrían los pobres, y llegaban a plantear la necesidad de la propiedad común.

En muy poco tiempo la violencia se convirtió en un ingrediente cotidiano en Bogotá y las refriegas produjeron víctimas. Los democráticos eran acusados de querer apropiarse de los bienes de los ricos. Para los hombres de ruana, la práctica de la especulación por parte de algunos abastecedores permitía calificar a todos ellos de monopolistas y agiotistas.

${ }^{71}$ Gutiérrez, "Noticias", 1977, p. 194.
Muy lejos quedaban ya, pese al poco tiempo transcurrido, los elogios de 1850 a los artesanos por su carácter laborioso, pacífico y honrado, "su amor a las instituciones republicanas, su deseo de moralizarse en el seno del trabajo", su interés por fomentar las artes y participar en la vida pública. ${ }^{72}$

Se extendía ahora sobre esos virtuosos artesanos que habían impuesto al candidato liberal la mirada "desde arriba" de nacionales, diplomáticos y viajeros sobre las mayorías, descritas como ignorantes, poco afectas al trabajo, viciosas y alborotadoras. Ladrones eran considerados todos los que cuestionaban el derecho de propiedad.

En el marco de un clima enrarecido, el 20 de agosto los artesanos exigían el derecho al trabajo con cartelones que clamaban "pan, trabajo o muerte". Además de la protección ante las importaciones, exigían la creación de un taller nacional con aporte de capital del gobierno. No sólo gólgotas y conservadores, sino también propietarios obandistas repudiaban la insolencia de los democráticos. La inseguridad y la tensión aumentaban día a día.

Conservadores alarmados, o deseosos de disponer de armas, demandaron infructuosamente que el gobierno se las proporcionara. Democráticos y militares se reunieron aduciendo la amenaza de un intento para derrocar al gobierno. Los rumores sobre golpes de Estado de distinto signo habían sido frecuentes ya durante la presidencia de López; la dictadura parecía ahora inminente.

Lo que sucedió tiene, visto a la distancia, algo de inevitable. El gobierno legal, cercado por todos lados, era ya impotente para resolver la situación.

\footnotetext{
${ }^{72}$ Citado en Vargas, Colombia, 1972, p. 39.
} 


\section{La dictadura militar-democrática}

Según los relatos, el 16 de abril hombres de ruana se manifestaban ante el cuartel de artillería pidiendo armas. El 17 se concentraban 300 húsares en la plaza Bolívar y el general Melo montado en su zaino gritó: "Mueran los gólgotas", consigna que corearon militares y civiles.

Obando dimitió al negarse a asumir la suma del poder, ante un grupo de destacados dirigentes democráticos que se lo propusieron.

Fueren cuales hayan sido los motivos para la participación de Melo en los acontecimientos que lo condujeron a la dictadura, existe acuerdo en que los democráticos tuvieron un papel decisivo en su imposición.

Melo asumió el cargo de jefe supremo del Estado reuniendo las funciones que le atribuyera a la presidencia la Constitución de 1843. Los democráticos no consideraron incompatible la democracia con la dictadura. Por el contrario, justificaron su conducta en su condición de hombres libres unidos con sus "hermanos del ejército", contra los embaucadores y los demagogos.

Desde su perspectiva, la Constitución y la legitimidad eran "pretextos para engañar a los pueblos".

Desde el periódico El 17 de Abril se lanzaría la propuesta de reunir una Convención Nacional donde se expresara el pueblo sin la "interferencia de los políticos", al tiempo que para castigar el monopolio y cobrar fuertes derechos a las mercaderías extranjeras. ${ }^{73}$

\footnotetext{
${ }^{73}$ Ideas expuestas por Joaquín Posada Gutiérrez en el periódico mencionado, transcritas en ibid, 1972, pp. 90-91.
}

Fueron reestructurados el ejecutivo y el poder judicial, y se designaron nuevos gobiernos en los estados y municipios. Se convocó a las fuerzas armadas y milicias democráticas para defender el nuevo poder.

Se les garantizaron sus derechos a los extranjeros que ajustaran su conducta a las leyes y decretos y que acataran a las autoridades.

En El 17 de Abril se publicó el "Catecismo político de los artesanos y campesinos", que contenía respuestas a las acusaciones de la oposición. Sin duda el texto no llegó masivamente al campesinado, que durante los gobiernos de López y de Obando no había manifestado las inquietudes de los artesanos. Según Álvaro Tirado Mejía, los "indígenas y esclavos habían participado contra sus amos" en la guerra civil de $1841 .{ }^{74}$ Existía, como en el resto de Hispanoamérica, el bandolerismo rural, pero no se había producido nada parecido a un levantamiento campesino.

De todas manetas, los campesinos formarían parte en gran medida de los ejércitos que se levantaron contra la dictadura de Melo.

Desde el comienzo el nuevo gobierno procuró tranquilizar a las clases altas explicando que "no sabiendo estimar la moralidad de nuestras clases pobres creyeron que el momento del saqueo y de todos los excesos había llegado".75 Seguramente no confiaban demasiado en esta garantía. Si nos atenemos a Restrepo, todos los que tenían algo que perder estaban alarmados "por sus propiedades" y sus temores se fundaban "en los ofrecimientos" que se

\footnotetext{
74 Tirado, "Colombia", 1985, p. 117.

${ }^{75}$ Nota editorial de La Gaceta Ofirial, fechada
} el 17 de abril, en Gutiérrez, "Literatura", 1999, p. 197. 
habían hecho a los democráticos y en las "doctrinas" que se les habían inspirado "de que los bienes son comunes". ${ }^{76}$ Pese a la reiteración de las garantías y que incluso democráticos ministros y con otros elevados cargos de gobierno repudiaron los desórdenes, la buena voluntad de los propietarios, si es que existió, no duraría mucho.

Sin duda no podía reforzarla la imposición, el 25 de abril, de una derrama forzosa, ante el poco éxito del empréstito voluntario. Tampoco concitó adhesiones entre quienes tenían algo que perder la creación, al día siguiente, de un tribunal revolucionario con la función de juzgar a los enemigos y penar como conspiradores a quienes no hicieran efectivas las cantidades estipuladas por la derrama.

La oposición actuó rápida y eficazmente. Liberales y conservadores participaron en el gobierno que en nombre de la defensa de la Constitución y las leyes se instaló en Ibagué. Contó desde el comienzo con el apoyo de los representantes extranjeros y en particular del estadunidense. Reunió recursos en el país y en Estados Unidos para la adquisición de armas. En agosto ya estarían conformados los ejércitos dirigidos por ex presidentes, integrados, como era habitual, con campesinos, pero en los que revistaron también jóvenes de "buena familia".

Del odio desatado da cuenta, en el relato de Restrepo, que Camilo Rodríguez fuera calificado de criminal, esbirro y "famoso ladrón de las haciendas", y que el fallecimiento del artesano José Vega fuera considerado por el cronista "una fortuna para Bogotá". El encono se expresa tanto

${ }^{76}$ Restrepo, Diario, transcrito en Vargas, Colombia, 1972, p. 99. o más nítidamente cuando Restrepo al referirse al redactor de El 17 de Abril, Joaquín Posada, afirma que su muerte constituiría también una fortuna para los bogotanos. $^{77}$

Se ha atribuido a los errores tácticos de Melo su derrota militar. Desde una perspectiva más moderna se pone el acento en la pérdida de la legitimidad del discurso antipropietarista de los democráticos. Se analiza la contradicción, en definitiva insalvable, entre ese discurso y el que empezó a predominar desde el gobierno, que llegó incluso a reivindicar a los propietarios "como principal actor de la vida política" ${ }^{78}$ No era demasiado fácil atraer a las clases altas y al mismo tiempo imponerles coactivamente las pesadas contribuciones forzosas. Seguramente el discurso institucionalista fue más convincente para aquéllas en la medida en que fue ganando fuerza la oposición constitucionalista. En definitiva, las fuerzas sociales que apoyaron a Melo hasta el final eran débiles si miramos este proceso con una perspectiva histórica.

El 24 de noviembre ejércitos liberales y conservadores convergían sobre Bogotá. Siguieron días y semanas de lucha encarnizada que se prolongó hasta el 4 de noviembre. En esa resistencia desesperada participaron tropas y centenares de artesanos tuvieron también un papel destacado.

La victoria liberal-conservadora fue celebrada con tedeum, banquetes y saraos. Fue seguida de represión, con sus muertos, sus presos, sus desterrados y deportados a Panamá, donde las fiebres tropicales fungieron de verdugo sobre esos cuerpos nacidos en la sabana.

${ }^{77}$ lbid., p. 104.

${ }^{78}$ Gutiérrez, "Noticias", 1977, pp. 200-201. 
Algunas SOMERAS CONCLUSIONES

Como hemos visto, los tres casos analizados tienen en común el impacto del clima ideológico previo a las revoluciones del 48 -y el generado por éstas-sobre jóvenes liberales y sectores de artesanos, en la especial coyuntura de cada uno de sus países, sobre la cual procuran incidir.

Estas peculiares experiencias, que resultaron frustradas, serían irrepetibles. En la segunda mitad del siglo XIX los radicales chilenos, constituidos en partido, o los antiguos gólgotas colombianos integrando el Partido Liberal, no sin hacer referencia a la "revolución", serán ya más moderados y habrán abandonado el programa de reformas sociales que habían sustentado. Por su parte, los artesanos se agruparían en mutualidades, y un sector de ellos optaría por el utopismo socialista y el anarquismo.

Como tantos movimientos históricos derrotados, éstos dejan planteadas muchas interrogantes, entre ellas la de cuál fue la huella que imprimieron en la memoria histórica.

Más que la huella que estos cortos pero intensos episodios han podido dejar en sus países, resulta importante para todos los latinoamericanos la aproximación a opciones en torno a la democracia que atraviesan la historia de los siglos XIX y XX.

1) En Echeverría democracia es en primer lugar lo opuesto a tiranía y terror. Supuso la vigencia de libertades concretas, la existencia de formas de socialibilidad y asociación no controladas desde el poder, en definitiva, la construcción de una sociedad civil y de otro estilo de hacer política. En el discurso echeverriano en ningún caso la democracia queda confinada en el ámbito político. A la vez que la igualdad ante la ley, aparece la acción compensatoria hacia los pobres a cargo del Estado, como requisito mismo de igualdad. La ciudadanía, como sufragio y representación, requeriría la extensión de la educación al tiempo que la transformación del país mediante la industrialización.

Democracia aparece relacionada con el federalismo avasallado por Rosas y con el municipio como ámbito a partir del cual extender el sufragio "universal".

Democracia en el 48 para Echeverría implica regeneración de la sociedad, lo que permitiría superar el "proletarismo" y la explotación. No fue ésta la opción sobre la democracia que predominó en la Argentina posrosista.

2) En el discurso de algunos Iguales, de la sociedades democráticas y especialmente el de los más radicales entre sus protagonistas, la democratización de la sociedad fue un componente insoslayable de la democracia política y aun su misma esencia.

Según la expresión más explícita de Francisco Bilbao, democracia debía radicarse en el mundo de las ideas, en la educación, y raigalmente en la tierra y su propiedad. La democracia pura para Bilbao, como para Santiago Arcos, debía también tener como base el municipio. En los años finales de su vida, Bilbao aludiría a la democracia como esencia del republicanismo.

Para Arcos la democratización política requería la ruptura de las modalidades de control sobre los sectores populares por parte del sistema político y los terratenientes. La transformación del país, que incluía la inmigración, necesitąba en su opinión de una ciudadanía capaz de autodeterminarse y el acceso de los campesinos, mayoría absoluta de la población, a 
la propiedad de la tierra, lo que los haría independientes.

Dos ideas básicas de los Iguales en abril de 1850 son: que los artesanos incorporándose a la vida política y unidos podrían imponer mejores condiciones de trabajo, protección a la industria y financiamiento del gobierno para la educación de sus hijos. En segundo lugar, la práctica de la reunión y la discusión incidiría sobre el pueblo conduciéndolo pacíficamente por medio de la razón a una opción política inteligente. Aunque de manera embrionaria, esto constituyó un antecedente de una ciudadanía con requerimientos de justicia social.

En el discurso de los Iguales en la segunda mitad del año 1850 pasa a primer plano una versión de la democracia política, y aunque las demandas de tipo social de los artesanos quedan postergadas siguen participando, lo que da idea de la importancia que tenía, por lo menos para un sector de éstos, la democratización del sistema político. Para un sector de los liberales y los vialistas, que pasaron a dirigir la Sociedad de la Igualdad, el interés fundamental radicaba en la posibilidad de acceder al gobierno. Mientras, Bilbao confió en la viabilidad de una revolución.

3) Los democráticos neogranadinos y también los gólgotas opusieron el sufragio universal a la democracia ilustrada, que lo restringía a los propietarios. En la versión de gólgotas la democracia consistía además en la igualdad legal suprimiendo la esclavitud, la vigencia de libertades civiles y políticas y un sistema institucional con una amplia separación de poderes y una relațiva descentralización de los estados. Para los democráticos, que también postularon el sufragio universal, consistía en primer lugar en la participación polí- tica de los artesanos, con un papel predominante, organizados en las sociedades democráticas. En el discurso de algunos influyentes democráticos y en las prácticas políticas, la democracia no quedó limitada al accionar dentro de los marcos legales, sino que pudo coexistir con el desconocimiento del derecho positivo en nombre de los derechos humanos y de la justicia. De tal concepción de la democracia derivaría su compatibilidad con la dictadura en el periodo melista, aduciendo la necesidad de evitar la manipulación del pueblo por los políticos, por quienes se habían sentido traicionados. La propuesta de reunir una convención elegida por el pueblo, sin la intermediación de aquéllos, implicaba no delegar funciones en el gobierno de la dictadura. Son realmente significativos sus objetivos: la supresión de los monopolios (de los ricos, en la terminología dominante), la protección del trabajo eliminando la competencia de las importacionés, e incluso la supresión de la fractura producida en el pueblo por las leyes en materia religiosa. Sin duda este discurso resultaría atractivo para esas mayorías urbanas sumidas en la pobreza, de las que espontáneamente emergía una especie de clasismo de los de abajo, a quienes proporcionó un discurso elaborado.

Una vez en el gobierno, aun los ministros democráticos buscaron aplacar el conflicto social y proporcionar seguridades a los propietarios, en el marco de la guerra que acabó convirtiéndose en la instancia que decidió el futuro.

Para los constitucionalistas, por su parte, el punto esencial en lo inmediato era la recuperación del sistema institucional. Las diferencias en su seno eran tan importantes que pocos años después desembocarían en la guerra civil entre liberales - para quienes 
el federalismo incluía una extremada autonomía de los estados- y conservadores, enfrentados en este aspecto y en otros, particularmente en torno a los avances en la secularización del Estado y la desamortización de los bienes del clero. Los conservadores descartaban la democracia en cualquiera de sus versiones. Aprobadas las medidas de 1851, la democratización de la sociedad no se contó entre las prioridades de los liberales.

Ninguna de las versiones que incluyeran como componente o como condición la democratización de la sociedad predominó en las últimas décadas del siglo XIX en parte alguna de América Latina.

Es un tema aún irresuelto en el subcontinente los reclamos de otras formas de democracia, que combinen representación, ejercicio directo de la soberanía y participación, con efectiva democratización en sociedades polarizadas y pluriétnicas.

\section{FUENTES}

-Alberdi, Juan Bautista, Bases y puntos de partida para la organización política de la república Argentina, La Cultura Argentina, Buenos Aires, 1914.

- _La república Argentina 37 años después de su Revolución de Mayo" en Halperin, Proyecto, 1995.

-Arcos, Santiago, "Carta a Francisco Bilbao" en Alejandro Witker, Lecturas universitarias, UNAM, México, 1978.

-Arosemena, Justo, Panamá y nuestra América, UAM, México, 1981.

-Bilbao, Francisco, Obras completas, Imprenta de El Cotreo, Santiago, 1897-1898, t. III.

- _. "Apuntes cronológicos" en $\mathrm{La}$ América en peligro, Editorial Arcilla, Santiago de Chile, 1941.
_-_La sociabilidad chilena" en $L a$ América en peligro, Editorial Arcilla, Santiago de Chile, 1941.

-Botana, Natalio, "El liberalismo federal en Argentina. 1852-1930" en Carmagnani, Federalismos, 1996, pp. 227-240.

-Carmagnani, Marcello (coord.), Federalismos latinoamericanos. México/Brasil/Argentina, $\mathrm{FCE}$, México, 1996.

-Coatsworth, John H., "Patrones de rebelión rural en América Latina: México en una perspectiva comparativa" en Friedrich Katz (comp.), Revuelta, rebelión y revolución, Ediciones Era, México, 1988.

-Colombia boy, Siglo XXI Editores, Bogotá, 1985.

-Collier, Simon y William F. Sater, Historia de Chile, 1808-1994, Cambridge University Press, España, 1998.

-Chiaramonte, José Carlos, "El federalismo argentino en la primera mitad del siglo XIX" en Marcello Carmagnani (coord.), I'ederalismos latinoamericanos. México/BrasillArgentina, FCE, México, 1996.

-Echeverría, Esteban, Obras completas de Esteban Echeverria, Ediciones Antonio Zamora, Buenos Aires, 1951, vol. I.

—_, "Carta al gobernador de Entre Ríos Justo José de Urquiza" en Esteban Echeverría, Obras completas de Esteban Echeverria, Ediciones Antonio Zamora, Buenos Aires, 1951, vol. I, pp. 271-272.

-, "Discurso de introducción a una serie de lecturas pronunciadas en el 'Salón Literario' en setiembre de 1837" en Esteban Echeverría, Obras completas de Esteban Ecbeverria, Ediciones Antonio Zamora, Buenos Aires, 1951, vol. I, pp. 216-217.

- "Código o declaración de los principios que constituyen la creencia social de la república Argentina" en Carlos Rama, Utopismo socialista (1830-1893), Biblioteca de Ayacucho, Caracas, 1977. 
__. "Sentido filosófico de la Revolución de Febrero en Francia" en Halperin, Proyecto, 1995.

-Encina, Francisco A., Historia de Chile, Editorial Ercilla, Santiago, s. a., t. Xxiv.

-Escobar Rodríguez, Carmen, La revolución liberal y la protesta del artesanado, Sudamérica, Bogotá, 1990.

-Fabbri, Luce, "Italianos en el escenario rioplatense en los tiempos de Rosas y de la Defensa de Montevideo", Garibaldi, Asociación Cultural Garibaldina, núm. 4, 1988, Montevideo.

-Frías, Félix, "El triunfo del gobierno de Chile y la caída de la tiranía en la república Argentina" en Halperin, Proyecto, 1995.

-Gazmuri, Cristián, El " 48 " cbileno. Igualitarios, reformistas radicales, masones y bomberos, Editorial Universitaria, Santiago de Chile, 1992.

-Gelman, Jorge, "Un gigante con pies de barro. Rosas y los pobladores de la campaña" en Noemí Goldman y Renato Salvatore, CaudiLlos rioplatenses: nuevas miradas a un viejo problema, Eudeba, Buenos Aires, 1998.

-Goldman, Noemí y Renato Salvatore, Caudillos rioplatenses: nuevas miradas a un viejo problema, Eudeba, Buenos Aires, 1998.

González Bernaldo, Pilar, "Clubes electorales durante la secesión del estado de Buenos Aires (1852-1861). La articulación de dos lógicas de representación política en el seno de la esfera pública porteña" en Marcello Carmagnani (coord.), Federalismos latinoamericanos. Méxicol BrasillArgentina, FCE, México, 1996.

- Civilidad y política en los orígenes de la nación argentina. Las sociabilidades en Buenos Aires 1829-1862, FCE, Buenos Aires, 2000.

-Gutiérrez, Juan María, "Noticias biográficas sobre don Esteban Echeverría" en Carlos Rama, Utopismo socialista (1830-1893), Biblioteca Ayacucho, Caracas, 1977.

-Gutiérrez Sanín, "La literatura plebeya y el debate alrededor de la igualdad" en Sabato, Ciudadania, 1999.
-Halperin Donghi, Tulio, "Estudio preliminar" en Halperin, Proyecto, 1995.

- Proyecto y construcción de una nación (1846 1880), Compañía Editora Espasa Calpe Argentina Sociedad Anónima, Buenos Aires, 1995 (Ariel Historia).

-Historia de Belgrano y la independencia argentina, Editorial Juventud Argentina, Buenos Aires/Barcelona, 1983, t. II.

-Izquierdo, Gonzalo, Historia de Chile, Andrés Bello, Santiago, 1990, t. II.

-Jaramillo Uribe, Jaime, "Etapas de la historia de Colombia" en Mario Arruba $e t$ al., Colombia boy, Siglo XXI Editores, Bogotá, 1.985.

—_, "Las sociedades de artesanos", ponencia presentada en el Primer Encuentro de Historiadores de América Latina y el Caribe, UAM, México, 1974.

- La América en peligro, Editorial Ercilla, Santiago de Chile, 1941.

-Lastarria, José Victorino, "El manuscrito del diablo" en Alejandro Witker, Lecturas unin wrsitarias, UNAM, México, 1978.

-Leal, Juan Felipe y José Woldenberg, la clase obrera en la bistoria de México. Del Estado liberal a los inicios de la dictadura porfirista, Siglo XXI Editores/IIs-unAM, México, 1983.

-López Muñoz, Ricardo, La salvación de la América, Centro de Investigación Científica Ing. Jorge L. Tamayo, México, 1995.

-Lynch, John, Juan Manuel de Rosas, Emecé Editores, Buenos Aires, 1984.

-Mitre, Bartolomé, "Profesión de fe", "Libertad y justicia", "Ideas conservadoras de buena fe", en Halperin, Proyecto, 1995.

-Moreno Beauchemin, Ernesto, Historia del movimiento sindical chileno. Una visión cristianu, Instituto Chileno de Estudios Humanísticos, Santiago de Chile, 1986.

-Moreno Toscano, Alejandra, "Los trabajadores y el proyecto de industrialización. 1810)1867 " en Pablo González Casanova (coord.), Ia 
clase obrera en la bistoria de México, Siglo XXI Editores, México, 1983, t. I.

-Posada Carbó, Eduardo, "Alternancia y política. Elecciones en Nueva Granada y Venezuela. 1935-1937" en Sabato, Ciudadanía, 1999 , p. 175.

-Rama, Carlos, Utopismo socialista (18301893), Biblioteca Ayacucho, Caracas, 1977.

-Ramón, Armando de, "La mecánica del crecimiento urbano y su control. Santiago de Chile (1840-1910)", Siglo XIX. Revista de Historia, 2a. época, Instituto Mora, núm. 16, juliodiciembre de 1994, México.

- Breve bistoria de Cbile. Desde la imasión incaica basta nuestros dias (1500-2000), Editorial Biblos, Buenos Aires, 2001.

-Romero, Luis Alberto, La sociedad de la igualdad. Los artesanos de Santiago de Cbile y sus primeras experiencias políticas, 1820-1851, Instituto Torcuato di Tella, Buenos Aires, 1978 (Serie Historia).

-Sabato, H. (coord.), Ciudadanía política y formación de las naciones, FCE, México, 1999.

-Sala de Touron, Lucía y Rosa Alonso, El Uruguay comercial, pastoril y caudillesco, t. II. Sociedad, política e ideología, Ediciones de la Banda Oriental, Montevideo, 1991.
-Sarmiento, Domingo F., "La revolución francesa de 1848" en Halperin, Proyecto, 1995.

-Ternavasio, Marcela, "Entre la deliberación y la autorización. El régimen rosista frente al dilema de inestabilidad política" en Goldman y Salvatore, Caudillos, 1998.

-Tirado Mejía, Álvaro, "Colombia, siglo y medio de bipartidismo" en Mario Arruba et al., Colombia boy, Siglo XXI Editores, Bogotá, 1985.

- Vargas Martínez, Gustavo, Colombia 1854: Melo, los artesanos y el socialismo, La Oveja Negra, Medellín, 1972.

-Vicuña Mackenna, Benjamín, Los girondinos cbilenos, Editorial Universitaria, Santiago de Chile, 1989.

-Witker, Alejandro, Lecturas universitarias, UNAM, México, 1978, pp. 75-78.

-Zubillaga, Carlos, "El pensamiento socialista en el Uruguay. La reflexión precursora" en Manuel A. Claps (coord.), Ensayos en bomenaje al doctor Arturo Ardao, Facultad de Humanidades y Ciencias de la Educación, Departamento de Publicaciones-Universidad de la República, Montevideo, 1995. 